Gregory, P. H., Guthrie, E. J. \& Bunce, M. E. (1959). J. gen. Microbiol. 20, 328-354

\title{
Experiments on Splash Dispersal of Fungus Spores
}

\author{
By P. H. GREgORY*, E. J. GUTHRIE, $\dagger$ AND MAUREEN E. BUNCE* \\ Department of Botany, Imperial College of Science and Technology, London, S.W. 7
}

SUMMARY : Splash dispersal (first studied by Faulwetter, 1917 $a, b$ ) is characteristic of many bacterial plant pathogens and slime-spored fungi. The mechanism of splash has been studied in the laboratory under simplified conditions with water drops falling from known heights on to thin films of a suspension of conidia of Fusarium solani spread on horizontal glass surfaces. The resulting splash droplets were caught, counted and measured by the naphthol green B slide method (Liddell \& Wootten, 1957). Both the total number of droplets produced and of those carrying spores increased as the film thickness decreased, and as the size and velocity of the incident drop increased.

One incident drop $5 \mathrm{~mm}$. in diameter falling on a horizontal film of spore suspension $0.1 \mathrm{~mm}$. thick on a glass surface produced over 5200 splash droplets of which over 2000 carried one or more spores. The sizes of splash droplets ranged from $5 \mu$ to about $2400 \mu$, and their size distribution was of the log probability type. The median diameter was 70 $\mu$ for all droplets, and $140 \mu$ for droplets carrying spores. The medium horizontal distances travelled by these droplets in still air was 10 and $20 \mathrm{~cm}$. respectively. Increasing the film thickness to 0.5 and $1.0 \mathrm{~mm}$. reduced the total resulting droplets to 3500 and 2100 (1600 and 500 carrying spores), respectively. Neither median diameter nor median distance of horizontal travel were much altered by varying the diameter of incident drop or film thickness. Droplets of diameters between 164 and $655 \mu$ tended to travel further than either smaller or larger droplets. Small spores such as those of Gloeosporium album, Colletotrichum lindemuthianum and Nectria cinnabarina were even more readily picked up from suspension than the macroconidia of Fusarium solani.

The number of droplets deposited per unit area on a horizontal plane decreased rapidly with increasing distance from point of impact, and in still air few droplets travelled beyond $70 \mathrm{~cm}$.

Splash on a twig bearing conidial fructifications of Nectria cinnabarina produced 2000 spore-carrying droplets, and the sequence of events is shown by high-speed photography.

A splash droplet consists of an intimate mixture of liquid from both the incident drop and the surface film. The larger splash droplets contain spores if either the incident drop or the surface film is a spore suspension. Both raindrops falling at terminal velocity and drops falling more slowly from vegetation may operate the splash dispersal mechanism. Splash in rain or drip from trees may act as a complete dispersal mechanism in still air, or as a 'take-off' mechanism leading to dispersal by wind. Both functions are important in plant epidemiology.

Many fungi have mechanisms liberating their spores into dry air and their dispersal has been studied extensively. Many others produce their spores embedded in mucilage, which, as shown by Stepanov (1935), prevents their removal by wind. Field workers recognize that some of these slime-spored fungi are spread by insects while others may be spread by the action of rain

* Present address : Rothamsted Experimental Station, Harpenden, Hertfordshire.

$\dagger$ Present address: Plant Breeding Station, Njoro, Kenya. 
and wind together. Faulwetter $(1917 a, b)$ splashed dyes on white paper, and acetic acid on litmus paper, in seeking an explanation of dispersal of bacterial crop-pathogens by the action of rain splash and wind. Little is known about spore dispersal by rain splash, in spite of the part it apparently plays in many economically important crop diseases, such as Gloeosporium rot of apples, black-arm (Xanthomonas malvacearum) of cotton, dry rot (Diplodia zeae) of maize, and celery leaf spot (Septoria spp.).

Raindrops vary in size from $\mathbf{0 . 2}$ to about $5 \cdot 0 \mathrm{~mm}$. diam. (drops larger than this are unstable and break up before reaching terminal velocity), and they fall at terminal velocities varying from $1.0 \mathrm{~m}$. $/ \mathrm{sec}$. for drops $1 \mathrm{~mm}$. diam. to $7 \cdot 8 \mathrm{~m}$. $/ \mathrm{sec}$. for drops $5 \mathrm{~mm}$. diam. Small raindrops normally greatly outnumber larger ones, but rain from convective or thunder clouds has relatively more large drops than have frontal or orographic rain (Mason, 1957).

Knowledge of the events during a splash comes from studies of water drops in the laboratory by Worthington \& Cole (1897) and Edgerton \& Killian (1939); and from a theoretical and experimental study by Engel (1955). But most of these studies are inapplicable in detail as they deal with splashes from drops falling on deep layers of liquid or on dry surfaces. Splash on a deep layer usually produces a bubble (Blanchard \& Woodcock, 1957). In splash from a thin film bubbles are seldom observed and the sequence of events is illustrated by Edgerton's beautiful photograph which forms the frontispiece to the new edition of d'Arcy Thompson's Grorth and Form.

Data from all these sources suggest the following sequence of events. When a raindrop falls on a horizontal surface covered with a thin film of water a crater-shaped wall of liquid is formed. The wall of the crater moves outwards and upwards, the rim breaks up under surface tension into rays, and these rays in turn break up into chains of minute droplets which are shot from the ends of the rays into the air in an upward and outward direction. The trajectory of these droplets is determined by gravity and friction between the minute droplets and the air. Ultimately the droplets will be deposited on a surface or they will evaporate.

The sequence of events when micro-organisms are dispersed by rain splash is envisaged as follows. Dry spores are held firmly to their substratum by the mucilage in which they are embedded. When rain comes the first drops merely wet the surface, swelling the mucilage and allowing the spores or bacteria to float in a film of water (Nisikado, Inouye \& Okamoto, 1955). From this film they are removed in the splash droplets thrown into the air by impact when succeeding raindrops strike the surface film. The object of our work was to estimate the number and spore-carrying power of droplets produced by splash under various conditions.

\section{METHODS}

Drops of tap-water (incident drops) were allowed to fall vertically from known heights in still air in the laboratory on to thin layers of spore suspension spread on horizontal glass slides (target films). The droplets thrown up by the splash (splash droplets) were sampled to determine their numbers, size, distance of 
travel in still air, and whether or not they carried spores. The splash pattern was reconstructed from samples of the resulting droplets collected on $3 \times 1$ in. microscope slides placed horizontally on the same level as the target film of spore suspension and at various distances. Preliminary tests by Guthrie (1957) on methods of studying the droplets resulting from a splash led to the adoption of the naphthol green B slide detection method developed at Porton by Liddell \& Wootten (1957) for determining droplet size distributions in fog by using a Cascade Impactor. Droplets are caught on microscope slides coated with a thin layer of gelatine dyed with naphthol green B. Each droplet leaves a circular 'stain' with a clear centre and defined dark green margin that can easily be measured under a low-power microscope. The relation between stain diameter and droplet diameter is determined by calibration with droplets of known diameter. Preliminary tests gave reproducible results when an average of five or ten splashes was taken. The methods used in the main series of experiments were modified as required for individual tests as described in later sections.

Production of incident drops. In imitation of raindrops, tap water was dropped from the end of vertical pipettes held at the required height near the ceiling of the laboratory or hall in a tower constructed from 'Dexion'. The drop sizes used were approximately $2 \cdot 0,3 \cdot 0,4 \cdot 0$ and $5 \cdot 0 \mathrm{~mm}$. in diameter. The end of the pipette was ground smooth and coated with silicone grease. Its outside diameter was $2.0 \mathrm{~mm}$. for $4.0 \mathrm{~mm}$. diam. drops, and $4.5 \mathrm{~mm}$. for $\mathbf{5} \cdot 0 \mathrm{~mm}$. drops. For smaller drops glass capillaries were drawn out to $\mathbf{0 . 2} \mathrm{mm}$. outside diam. for $2 \mathrm{~mm}$. drops or slightly larger for $\mathbf{3 . 0} \mathrm{mm}$. drops and were allowed to drip continuously under a constant head of water. Except for the largest drops from the greatest height, all drops were shielded from air currents during fall by a vertical asbestos-cement pipe $(11 \mathrm{~cm}$. internal diam.) attached to the Dexion tower. During an experiment pipettes were allowed to drip continuously on to a wooden or blotting-paper shutter which was removed only when a drop was required to hit the target film.

Target film. The target film normally consisted of a suspension of conidia of Fusarium solani in distilled water. Conidia were produced on cultures of potato glucose agar in $6 \mathrm{oz}$. medical flats. At the suggestion of Dr E. W. Buxton the cultures for some of the experiments were grown under continuous fluorescent lighting to suppress microconidia and obtain almost pure macroconidia. When the cultures were sporulating the conidia were washed off in $20 \mathrm{ml}$. water $/ 2$ medical flats, and the concentration of a $1 / 10$ dilution determined with a haemocytometer. Two bottles normally gave a concentration of about $16 \times 10^{6}$ macroconidia $/ \mathrm{ml}$.

The target film was placed in a $6 \cdot 6 \mathbf{~ c m} .{ }^{2}$ area marked with grease pencil on a microscope slide which had been cleaned by flaming after soaking in ethanol. Three film thicknesses were used, $0 \cdot 1,0.5$ and $1 \cdot 0 \mathrm{~mm}$. The required volume of spore suspension was placed on the area from a pipette, care being taken to spread the film evenly because the thinnest films tended to contract under surface tension.

Because the conidia sank to the bottom of the film it was decided to have a 
constant number of spores/unit area of the target film. A concentration of $16 \times 10^{6}$ macroconidia $/ \mathrm{ml}$. was used for the film $0.1 \mathrm{~mm}$. thick, and $1 / 5$, and $1 / 10$ dilutions for the 0.5 and $\mathbf{1 . 0} \mathrm{mm}$. films, respectively, all thus giving $c$. 160,000 macroconidia $/ \mathrm{cm} .{ }^{2}$ of target film. Each slide was normally used as target for one falling drop only (occasionally for two to five splashes by the smallest drops).

Sampling slides. The naphthol green B slides on which the splash droplets were caught were prepared according to the recommendations of Liddell \& Wootten (1957). To purify the dye $10 \mathrm{~g}$. of naphthol green B (British Drug Houses Ltd.) was dissolved in $50 \mathrm{ml}$. boiling water. On cooling it was salted out by adding $10 \mathrm{~g}$. powdered anhydrous sodium acetate and allowing to stand for several days at $4^{\circ}$. The mixture was then filtered and the filter cake extracted with boiling absolute ethanol until the sodium acetate was removed.

Purified naphthol green B (1 g.) was dissolved in 20 ml. warm distilled water, filtered and added to $10 \mathrm{ml}$. of a $4 \%(\mathrm{w} / \mathrm{v})$ solution of gelatine, and used to coat the slides on which splash droplets were caught. Microscope slides $(3 \times 1$ in.) were washed in detergent and dipped in ethanol before polishing with a cloth. Two drops of naphthol green B gelatine solution were placed on the slide and spread evenly with the edge of another slide.

Slides for use near the target film had arcs $1 \mathrm{~cm}$. apart drawn on the back. The arrangement of slides for sampling a splash is shown in Fig. 1. Slides were placed along one radius only, with the point of impact as centre, and arranged at intervals up to $100 \mathrm{~cm}$. from the point of impact. Each experiment was normally based on five to ten separate splashes to avoid asymmetry in a single splash and to obtain enough droplets to give a reliable count at the greatest distances. After exposure the slides were scanned under a microscope provided with a mechanical stage, the area actually scanned being assumed to be a representative sample of its annulus (Fig. 1). The total number of droplets was estimated by multiplying by the appropriate factor. The path followed in scanning varied according to the proximity of the zone to the target area. The path is shown by the dotted line on Fig. 1. Each stain in the area scanned was measured and the number of macroconidia recorded (a value of over 60 macroconidia was classified as 'numerous').

Calibration of the naphthol green slide method. The method of calibration was based on that of Courshee \& Byass (1953) in which a spinning disk apparatus was used to produce a spray of uniform droplets whose sizes were measured directly by catching a sample in oil. Other drops were caught on naphthol green slides and the size of the stain measured. A Perspex disk of diameter $4 \frac{1}{2}$ in. was fitted on a 1/20th horse-power high-speed motor and water fed on to the upper surface of the disk at a rate of $8 \mathrm{ml} . / \mathrm{min}$. The motor was mounted inside a box which also acted as a shield, and a narrow band of spray droplets emerged through a slot cut in the side of the box. We are indebted to Mr J. B. Byass of the National Institute of Agricultural Engineering who suggested the method and who lent a suitable motor for the spinning disk.

For the direct measurement of droplet sizes the droplets were caught on a layer of a $24 \%$ 'Vaseline' $+76 \%$ liquid paraffin $(w / v)$ mixture and covered 


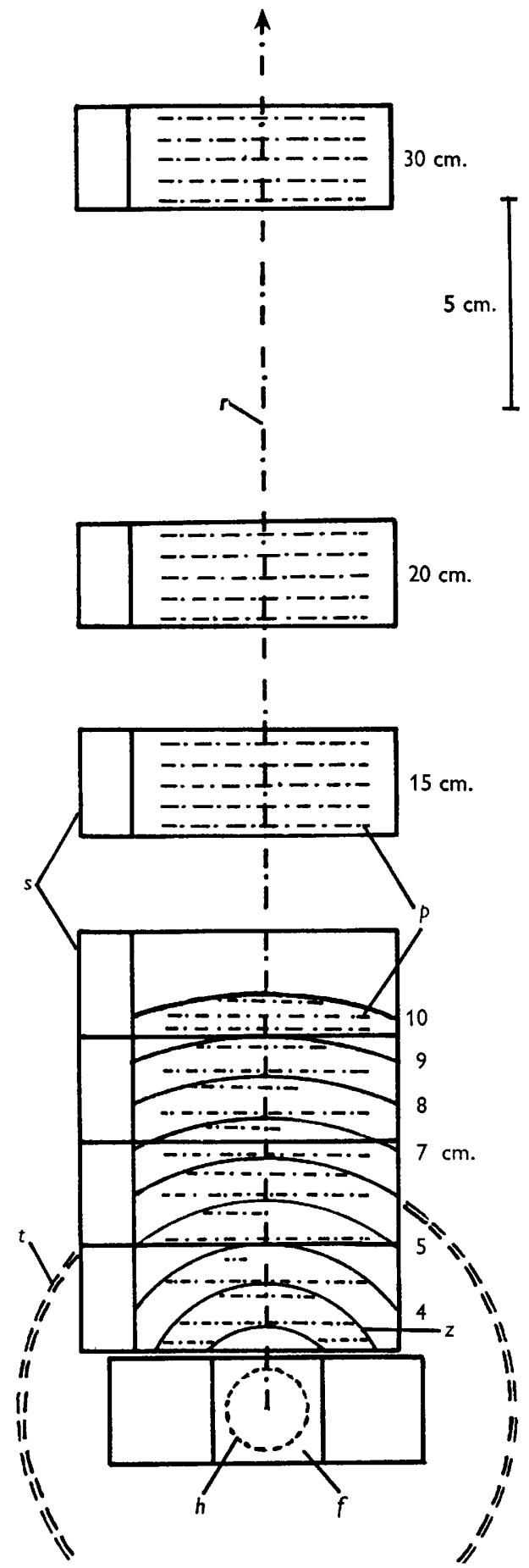

Fig. 1. Arrangement of target film, sampling slides and shields. $f=$ target film; $h=$ hole in Perspex shield; $p=$ scanning path; $s=$ sampling slides; $r=$ radius from splash; $t=$ asbestos pipe; $z=$ zone limit. 
as soon as possible (about $10 \mathrm{sec}$.) with pure liquid paraffin to prevent further evaporation.

As a first step to calibration evaporation curves were plotted for uncovered droplets of a range of sizes by focusing a microscope on the surface of the oil mixture in a measuring cell placed in the direct spray from the spinning disk. As soon as a droplet fell on the oil in the field of the microscope it was measured with a micrometer eyepiece and further measurements made at intervals of 15 sec. until the droplet had evaporated completely or had sunk into the oil. The sizes were then plotted and the \% evaporation in the first $10 \mathrm{sec}$. for each size of droplet examined was obtained from the resulting graphs. These figures for $\%$ evaporation were then plotted (Fig. 2), from which the loss by evaporation in 10 sec. by a droplet of any size could be estimated.

In each calibration experiment the speed of the spinning disk was regulated by rheostats to give spray droplets of the required size. One cell containing a layer of the liquid paraffin + 'Vaseline' mixture, and two naphthol green slides were then exposed to the spray about 2 feet below the level of the disk. The droplets on the oil were covered with liquid paraffin as quickly as possible and the sizes of 10 droplets measured with a micrometer eyepiece. The observed size of the droplets was then corrected for evaporation as shown in Table 1.

Table 1. Calculation of corrected droplet size

Measured
droplet
diameter
$(\mu)$
129
181
328
483
707
$\mathbf{7 7 5}$
836
884
887
1018

$\begin{array}{cc}\begin{array}{c}\text { Percentage } \\ \text { evaporation } \boldsymbol{E} \\ \text { (from Fig. 2) }\end{array} & \begin{array}{c}\text { Value of } \\ 100 / x\end{array} \\ \mathbf{3 \cdot 9} & 104 \cdot 1 \\ 3 \cdot 1 & 103 \cdot 2 \\ 1 \cdot 6 & 101 \cdot 6 \\ 1 \cdot 1 & 101 \cdot 1 \\ 0 \cdot 8 & 100 \cdot 8 \\ 0 \cdot 75 & 100 \cdot 8 \\ 0 \cdot 7 & 100 \cdot 7 \\ 0 \cdot 6 & 100 \cdot 6 \\ 0 \cdot 6 & 100 \cdot 6 \\ 0.5 & 100 \cdot 5\end{array}$

$\begin{array}{cc}\begin{array}{c}\text { Corrected } \\ \text { droplet } \\ \text { diameter }\end{array} & \begin{array}{c}\text { Stain } \\ \text { diameter }\end{array} \\ (\mu) & (\mu) \\ 134 & 396 \\ 186 & 530 \\ 333 & 1064 \\ 488 & 1503 \\ 713 & 2226 \\ 781 & 2435 \\ 842 & 2780 \\ 889 & 3266 \\ 892 & 3352 \\ 1023 & 3566\end{array}$

Percentage evaporation after 10 sec. $(E)$ was obtained from Fig. 2 and subtracted from 100 to give $x$.

Five splash droplet stains near the centre of each naphthol green slide were then measured in two directions at right angles. It was found that differences in the thickness of the naphthol green film could lead to differences of up to $10 \%$ in the stain size, and care was therefore taken to use films of equal thickness as judged against a colour standard.

Measurements were made on droplets in the size range $100-1000 \mu$, the limits being set by the ability of the available spinning disk apparatus to produce spray of uniform-sized droplets. The disk would in fact produce droplets much smaller than $100 \mu$ in diameter, but the turbulence created by the disk at high speeds mixed the droplets (normally separated by the effect of centrifugal force) and gave a spray of droplets of mixed sizes. 
The difficulty at the upper limit was caused by fluctuations in the mains voltage. The motor was running at very low speeds when producing droplets of more than $1000 \mu$ diameter, and was consequently very sensitive to alterations of voltage. Because no means of 'smoothing' the mains current was available to us the top end of the size range was not explored fully.

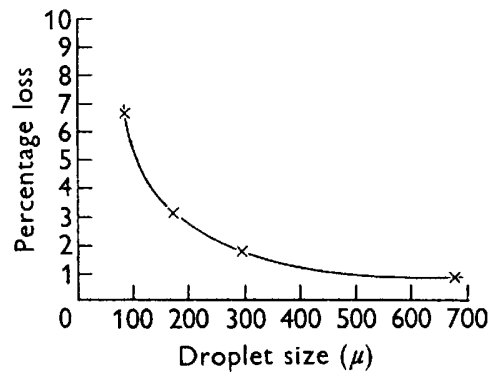

Fig. 2

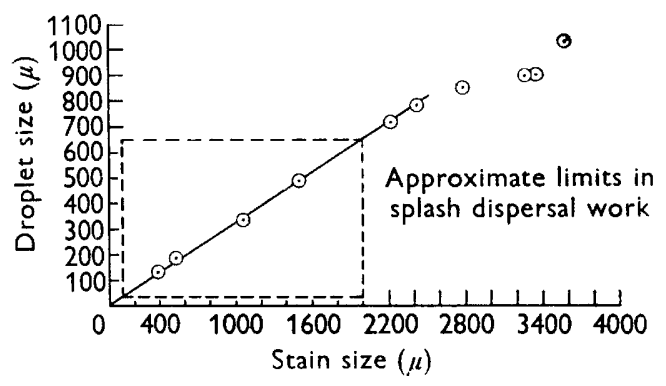

Fig. 3

Fig. 2. Percentage loss of diameter by evaporation in 10 sec. of droplets from spinning disk.

Fig. 3. Calibration of naphthol green slides with droplets from spinning disk. The relationship between stain size and droplet size.

When the corrected droplet sizes were plotted against stain sizes (Fig. 3), over most of the range the points lay on a straight line which passed through zero when extrapolated back. The mean stain size:droplet size ratio for the first six points on Fig. 3 is 3.094:1; the line drawn through these points is based on this ratio. The factor $0.32(=1 / 3.094)$ has been used to convert stain size to droplet size. For droplets of diameter $>800 \mu$ the relative size of the stain decreases, presumably because of evaporation and surface tension.

Performing the experiment. The pipette was adjusted for height and size of drop, and set to drip with the shutter in the closed position over the target. Beneath the shutter was a hole $2 \mathrm{~cm}$. diam. (through which the drops were aimed) cut in a square of Perspex. The hole was surrounded by a pad of blotting paper to absorb any drops which missed the hole. The green slides were placed at predetermined distances along a radius, and finally the target film was placed under the hole. The target area was screened from draughts with Polythene sheeting. When all was ready the shutter was opened and one drop allowed to fall through the hole on to the target. The shutter was then closed while a new target film was placed in position and reopened for another drop to pass. Droplets from five splashes were collected on one set of naphthol green slides.

An experiment normally consisted of ten splashes, but all data are calculated for a single splash, and as we are concerned with dissemination of pathogens emphasis is on droplet numbers, rather than volume of liquid splashed. 


\section{RESULTS}

\section{Results from preliminary experiments}

Preliminary experiments showed that the number and sizes of droplets produced by a splash were controlled by: (1) size of drop; (2) velocity of fall of drop (height from which it fell); (3) thickness of surface film (Fig. 4). The main series of experiments described in later sections was designed to explore the effect of these factors, and was performed after preliminary experiments had led to the technique being standardized.

The surface tension of the incident raindrop would normally be higher than that of the surface film containing mucilage. Variation in surface tension of the liquids over the range likely to be encountered in rain splash under field conditions did not affect numbers of droplets (Tests 1 and 2 in Table 2) or the distances travelled.

Table 2. Preliminary tests of relation between thickness of surface film and number of droplets produced

Incident drops $5 \mathrm{~mm}$. diam. falling $2 \cdot 9 \mathrm{~m}$.

\begin{tabular}{cccc}
$\begin{array}{c}\text { Test } \\
\text { number }\end{array}$ & $\begin{array}{c}\text { Thickness } \\
(\mathbf{m m} .)\end{array}$ & \multicolumn{1}{c}{ Composition } & $\begin{array}{c}\text { Surface film } \\
\text { Estimated total } \\
\text { number of droplets }\end{array}$ \\
1 & $\mathbf{0 \cdot 1}$ & Tap water & $1085(100 \%)$ \\
2 & $\mathbf{0 \cdot 1}$ & Spore suspension & $1055(97 \%)$ \\
3 & $\mathbf{0 \cdot 2}$ & Spore suspension & $868(80 \%)$ \\
4 & $\mathbf{1 \cdot 0}$ & Spore suspension & $462(43 \%)$ \\
5 & Nil & Dry glass slide & $27(2 \cdot 5 \%)$
\end{tabular}

As shown in Table 2 the number of droplets increased as the target film decreased in depth, but splash on a dry surface, as already noted by Faulwetter $(\mathbf{1 9 1 7} b)$, produced very few droplets. Our data give no indication of the boundary between these conflicting trends and the experimental limit is set by the difficulty of producing very thin films of liquid for test.

Comparison between naphthol green slides and culture dishes. In two experiments both naphthol green slides and Petri dishes containing potato glucose agar were exposed simultaneously, alternating along two radii, the positions of dishes and slides being interchanged at each replicate of three or six drops. Target films, $0.15 \mathrm{~mm}$. thick, contained 5 million spores $/ \mathrm{ml}$. of Fusarium solani macroconidia in one experiment and of Colletotrichum lindemuthianum in the other. After exposure the Petri dishes were incubated, and colonies counted on an illuminated screen every few hours. The highest count, before individual colonies merged, was taken as the total for the plate.

As indicated in Fig. 5, at $10 \mathrm{~cm}$. distance the number of colonies was fewer than the number of drops; the reasons are discussed below. The numbers of droplets carrying Colletotrichum spores were consistently higher than those carrying Fusarium spores. A similar effect is discussed in the next paragraph. 


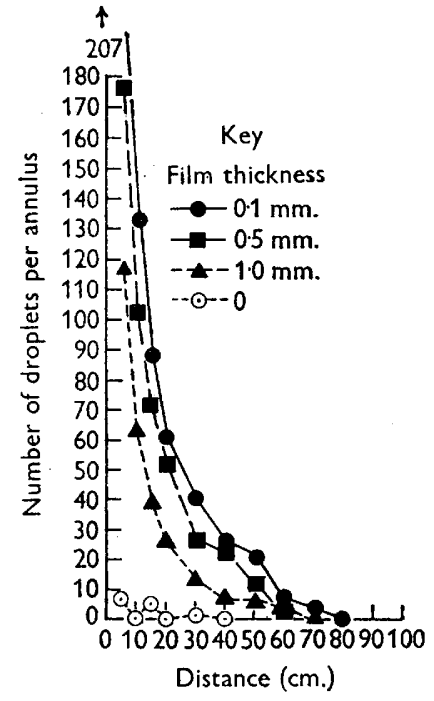

Fig. 4

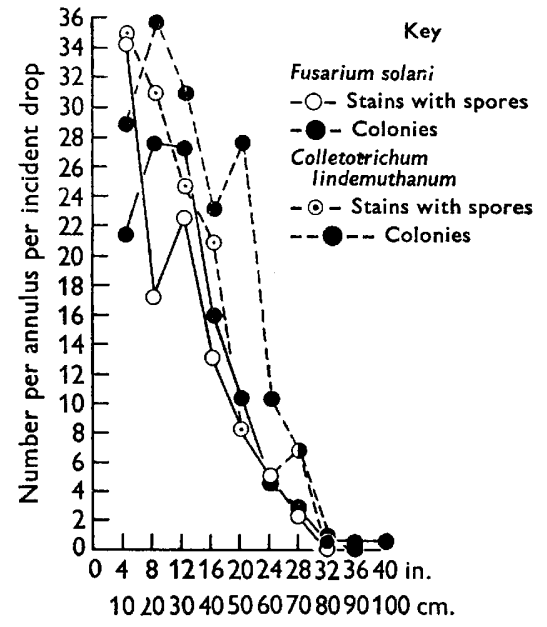

Fig. 5

Fig. 4. Effect of differences in thickness of target film on splashes from drops $5 \cdot 0 \mathrm{~mm}$. in diameter.

Fig. 5. Comparison of the numbers of droplet stains with spores on naphthol green slides with numbers of colonies on plates.

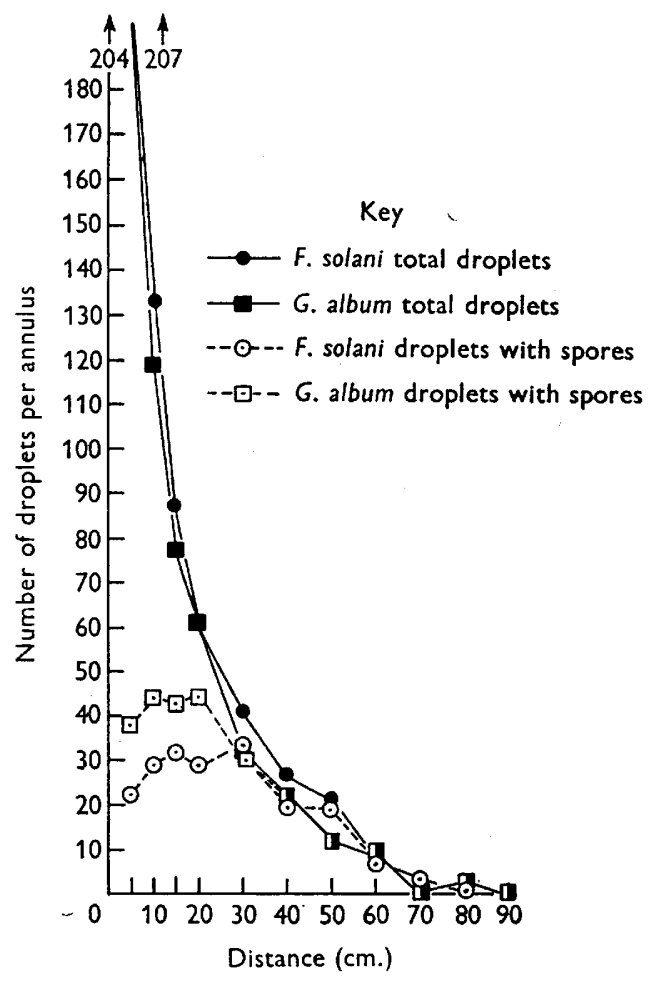

Fig. 6. Effect of variation in the spore type in the target film. 
Transport of spores by droplets. Preliminary experiments with target films $0.1 \mathrm{~mm}$. thick containing suspensions of macroconidia of Fusarium solani and conidia of Gloeosporium album, respectively, both at a concentration of $5 \times 10^{6} / \mathrm{ml}$, are shown in Fig. 6. The incident drops in both experiments were $5 \mathrm{~mm}$. diam. falling $2.9 \mathrm{~m}$. Three drops were used in each test for distances up to $50 \mathrm{~cm}$. and six drops for greater distances. Each test consisted of four replicates.

Spores of Gloeosporium album were carried by more splash droplets than those of Fusarium solani. The total numbers of droplets falling at distances up to $20 \mathrm{~cm}$. were similar in both experiments, but spores of $F$. solani were carried by only $65 \%$ of the number of droplets which carried $G$. album. The mean length of conidia in G. album is only about two-thirds of that in F. solani, and it appears that small spores such as those of G. album and Colletotrichum lindemuthianum are more easily picked up in splash droplets.

Experiments with bacteria. Preliminary tests with Escherichia coli were also made and numerous colonies obtained when Petri dishes of nutrient agar were exposed to splash. The results, however, were very irregular; colonies were often found in groups and it was difficult to determine whether some had come from one or from several droplets. Naphthol green slides were not exposed because of the difficulty of locating single bacteria during scanning.

\section{Main series of experiments}

The main series of experiments was designed to measure the effects of dropsize, film thickness and terminal velocity as obtained from different heights of fall on the formation and scatter of droplets.

Conditions fixed. Horizontal target film as source; number of macroconidia of Fusarium solani/unit area of target film, $16 \times 10^{4} / \mathrm{cm} .{ }^{2}$; still air, in laboratory screened from draughts; trapping surface horizontal, on level with target film, over distance $2-100 \mathrm{~cm}$. from impact.

Conditions uncontrolled. Ambient temperature, humidity and pressure of the air; surface tension of tap water and spore suspension; electrostatic charge on drops, film, etc.

Conditions varied. Diameter of incident drop: 2, 3, 4 and $5 \mathrm{~mm}$.; thickness of target film: $0 \cdot 1,0.5$ and $1.0 \mathrm{~mm}$.; height of fall of drop (controlling energy and velocity of drop at impact) $2 \cdot 9$ and $7 \cdot 4 \mathrm{~m}$.

Table 3 shows the estimated sizes and other properties of the drops actually used. The two heights of fall chosen were a compromise between the greater height required to allow the drop to attain its terminal velocity and the need to hit a small target after falling through air. Terminal velocities are estimated by plotting the data of Laws (1941), Gunn \& Kinzen (1949), and Best (1950). Velocity on impact was estimated from Laws (1941, fig. 5). For simplicity diameters of drops will be given to the nearest millimetre.

Data from a typical experiment. The data obtained are illustrated by details of a typical experiment using the standard methods. The experiment chosen is that of an incident drop $5 \mathrm{~mm}$. in diameter falling from a height of $7 \cdot 4 \mathrm{~m}$. on to a film $0 \cdot 1 \mathrm{~mm}$. thick-the drop with the greatest kinetic energy tested. 
The estimated numbers of droplets produced in one splash are shown in Table 4. Although the number of conidia in each droplet was counted, the Table shows only the numbers of droplets with or without macroconidia.

Table 3. Estimated diameters, terminal and impact velocities, and kinetic energies of incident drops used in main series of experiments

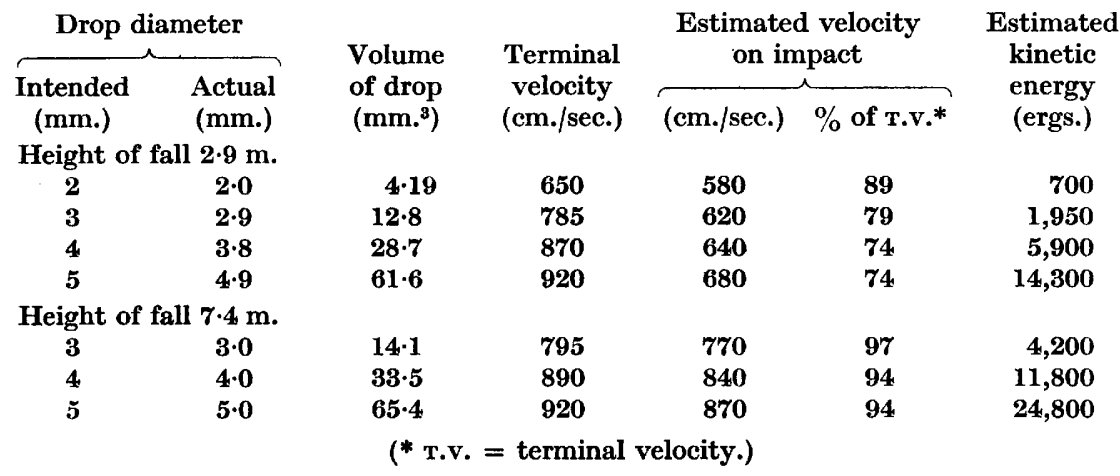

Total number of droplets (Table 5). The total number of droplets resulting from one splash increased consistently with increase in droplet size and increase in height of fall, but decreased with increasing film thickness; the number varied from about 180 to 5200 . The number of droplets carrying spores varied even more, from 24 droplets/splash of a $2 \mathrm{~mm}$. drop falling from a height of $2.9 \mathrm{~m}$. on a thick film, up to over 2000 spore-carrying droplets from a $5 \mathrm{~mm}$. drop falling at nearly its terminal velocity on to a thin film. The proportion of spore-bearing droplets varied from 14 to $47 \%$. For reasons discussed later the total number of droplets is probably underestimated.

Total volume of droplets. Table 6 gives an estimate of the total volume of droplets thrown up by one splash. The values are subject to large errors as droplet volumes were computed from mean diameters of a size category instead of from the individual stain sizes. The total is likely to be greatly affected by random errors in sampling a few larger droplets, some of which probably travelled beyond the limit of the range sampled. The total volume of droplets thrown up by a splash varied from one quarter to over twice the volume of the incident drop.

Droplet size spectrum. Droplet diameters were determined by measuring stains with the ordinary ocular micrometer linear scale. As usual in particle size studies the droplet diameters have been grouped for subsequent treatment into categories increasing by $\sqrt{ } 2$. The smallest droplets were in general most numerous and the voluminous data of the main series of experiments are most conveniently summarized by plotting the cumulative percentage of the number of droplets up to the limit of each size group on logarithmic probability paper (Fig. 7), fitting a freehand curve by eye and estimating the number median (50\% diameter). The 16 and $84 \%$ points are also estimated (Table 7 ) to enable the geometric standard deviation of the population to be estimated by the method of Drinker \& Hatch (see Green \& Lane, 1957). Median number 


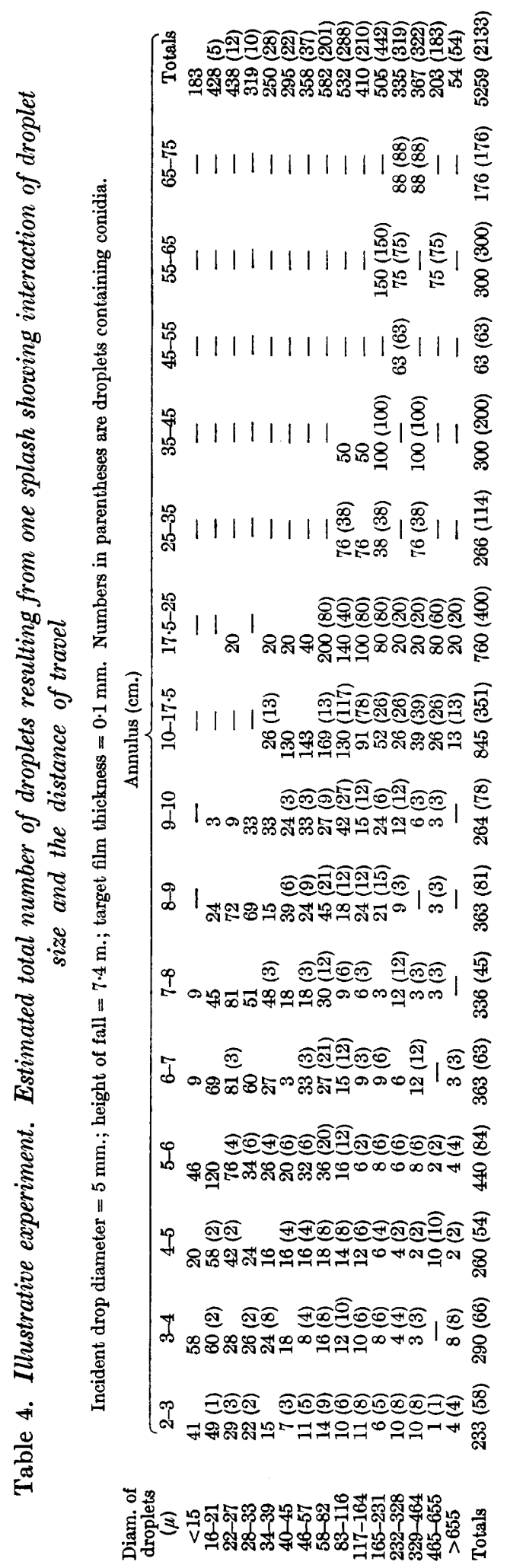


Table 5. Estimated total number of droplets resulting from one splash

Target film thickness

\begin{tabular}{|c|c|c|c|c|c|c|c|}
\hline \multirow[b]{2}{*}{$\begin{array}{c}\text { Height } \\
\text { of } \\
\text { fall } \\
\text { (m.) }\end{array}$} & \multirow[b]{2}{*}{$\begin{array}{c}\text { Diam. of } \\
\text { incident } \\
\text { drop } \\
\text { (mm.) }\end{array}$} & \multicolumn{2}{|c|}{$0.1 \mathrm{~mm}$} & \multicolumn{2}{|c|}{$0.5 \mathrm{~mm}$. } & \multicolumn{2}{|c|}{$1.0 \mathrm{~mm}$} \\
\hline & & $\begin{array}{c}\text { Total } \\
\text { droplets }\end{array}$ & $\begin{array}{c}\text { Droplets } \\
\text { with } \\
\text { spores }\end{array}$ & $\begin{array}{c}\text { Total } \\
\text { droplets }\end{array}$ & $\begin{array}{c}\text { Droplets } \\
\text { with } \\
\text { spores }\end{array}$ & $\begin{array}{c}\text { Total } \\
\text { droplets }\end{array}$ & $\begin{array}{c}\text { Droplets } \\
\text { with } \\
\text { spores }\end{array}$ \\
\hline $2 \cdot 9$ & 2 & 309 & 82 & 172 & 26 & 175 & 24 \\
\hline $2 \cdot 9$ & $\mathbf{3}$ & 828 & 348 & 563 & 109 & 487 & 82 \\
\hline $2 \cdot 9$ & 4 & 1470 & 567 & 993 & 211 & 817 & 127 \\
\hline $2 \cdot 9$ & 5 & 4110 & 1560 & 2470 & 829 & 1760 & 522 \\
\hline $7 \cdot 4$ & 3 & 1180 & 559 & 1020 & 283 & 1030 & 470 \\
\hline $7 \cdot 4$ & 4 & 4830 & 2010 & $\mathbf{3 0 2 0}$ & 603 & 2040 & 391 \\
\hline $7 \cdot 4$ & 5 & $\mathbf{5 2 6 0}$ & 2133 & $\mathbf{3 5 8 0}$ & 1690 & 2160 & 518 \\
\hline
\end{tabular}

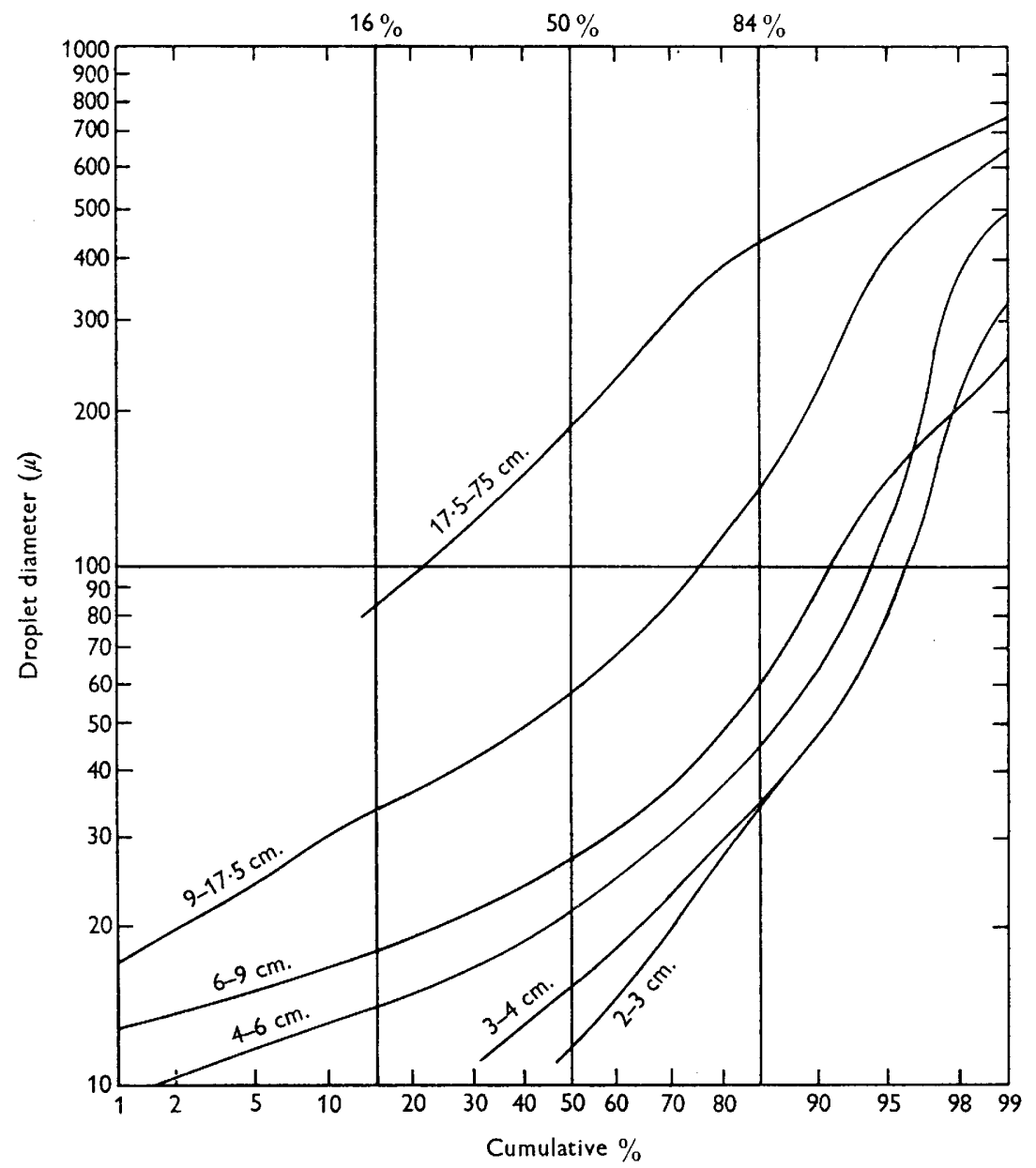

Fig. 7. Cumulative percentage of droplets plotted against increasing diameters shown at different distances for a splash from a drop $4 \mathrm{~mm}$. in diameter falling $7 \cdot 4 \mathrm{~m}$. into a target film $0 \cdot 1 \mathrm{~mm}$. thick. 
Table 6. Estimated total volumes of droplets resulting from one splash

\begin{tabular}{|c|c|c|c|c|c|}
\hline \multirow{3}{*}{$\begin{array}{l}\text { Height of } \\
\text { fall (m.) }\end{array}$} & \multirow{2}{*}{\multicolumn{2}{|c|}{ Incident drop }} & \multicolumn{3}{|c|}{ Target film thickness } \\
\hline & & & & & \\
\hline & Diameter & Estimated & Total vol. d & plets from & one splash $\left(\mathrm{mm} .^{3}\right)$ \\
\hline $2 \cdot 9$ & $\begin{array}{c}\text { (min.) } \\
2\end{array}$ & $\begin{array}{l}4 \cdot 2 \\
4 \cdot 2\end{array}$ & 1.6 & $2 \cdot 4$ & $2 \cdot 8$ \\
\hline $\mathbf{2} \cdot 9$ & 3 & $12 \cdot 8$ & 4.9 & $3 \cdot 9$ & $9 \cdot 7$ \\
\hline 2.9 & 4 & $28 \cdot 7$ & 12 & 12 & $8 \cdot 6$ \\
\hline $\mathbf{2 \cdot 9}$ & 5 & $61 \cdot 6$ & $\mathbf{5 8}$ & 56 & 37 \\
\hline $7 \cdot 4$ & $\mathbf{3}$ & $14 \cdot 1$ & $\mathbf{3} \cdot \mathbf{8}$ & 13 & 29 \\
\hline $7 \cdot 4$ & 4 & $\mathbf{3 3} \cdot \mathbf{5}$ & 50 & 27 & 41 \\
\hline $7 \cdot 4$ & 5 & $65 \cdot 4$ & $\mathbf{5 3}$ & 140 & 60 \\
\hline
\end{tabular}

Table 7. Estimated median droplet diameter (50\%) and geometric standard deviation $(\mu)$

Target film thickness (mm.)

\begin{tabular}{|c|c|c|c|c|c|c|c|c|c|c|}
\hline \multirow{2}{*}{\multicolumn{2}{|c|}{$\begin{array}{l}\text { Diam. of } \\
\text { incident } \\
\text { drop (mm.) }\end{array}$}} & \multicolumn{3}{|c|}{$0 \cdot 1$} & \multicolumn{3}{|c|}{0.5} & \multicolumn{3}{|c|}{$1 \cdot 0$} \\
\hline & & \multirow[t]{2}{*}{$16 \%$} & \multirow[t]{2}{*}{$50 \%$} & \multirow[t]{2}{*}{$84 \%$} & \multirow[t]{2}{*}{$\begin{array}{l}16 \% \\
\quad \mathrm{Di}\end{array}$} & $\mathrm{fo}_{50 \%}$ & $\begin{array}{l}84 \% \\
\mu)\end{array}$ & \multirow[t]{2}{*}{$16 \%$} & \multirow[t]{2}{*}{$50 \%$} & \multirow[t]{2}{*}{$84 \%$} \\
\hline \multicolumn{4}{|c|}{ Height of fall $2.9 \mathrm{~m}$} & & & & & & & \\
\hline $\mathbf{2}$ & $\begin{array}{l}\text { Total } \\
+ \text { spores }\end{array}$ & $\begin{array}{l}24 \\
90\end{array}$ & $\begin{array}{l}115 \\
250\end{array}$ & $\begin{array}{l}330 \\
310\end{array}$ & $\begin{array}{r}23 \\
270\end{array}$ & $\begin{array}{r}55 \\
340\end{array}$ & $\begin{array}{l}230 \\
460\end{array}$ & $\begin{array}{r}22 \\
160\end{array}$ & $\begin{array}{r}55 \\
460\end{array}$ & $\begin{array}{l}200 \\
700\end{array}$ \\
\hline $\mathbf{3}$ & $\begin{array}{l}\text { Total } \\
+ \text { spores }\end{array}$ & $\begin{array}{l}22 \\
84\end{array}$ & $\begin{array}{r}66 \\
190\end{array}$ & $\begin{array}{l}240 \\
350\end{array}$ & $\begin{array}{r}16 \\
130\end{array}$ & $\begin{array}{r}42 \\
240\end{array}$ & $\begin{array}{l}150 \\
440\end{array}$ & $\begin{array}{r}17 \\
380\end{array}$ & $\begin{array}{r}64 \\
510\end{array}$ & $\begin{array}{l}360 \\
650\end{array}$ \\
\hline 4 & $\begin{array}{l}\text { Total } \\
+ \text { spores }\end{array}$ & $\begin{array}{l}19 \\
70\end{array}$ & $\begin{array}{r}62 \\
160\end{array}$ & $\begin{array}{l}235 \\
460\end{array}$ & $\begin{array}{r}21 \\
105\end{array}$ & $\begin{array}{r}50 \\
290\end{array}$ & $\begin{array}{l}180 \\
600\end{array}$ & $\begin{array}{r}18 \\
185\end{array}$ & $\begin{array}{r}55 \\
220\end{array}$ & $\begin{array}{l}140 \\
600\end{array}$ \\
\hline 5 & $\begin{array}{l}\text { Total } \\
+ \text { spores }\end{array}$ & $\begin{array}{l}25 \\
80\end{array}$ & $\begin{array}{r}92 \\
240\end{array}$ & $\begin{array}{l}270 \\
480\end{array}$ & $\begin{array}{r}23 \\
110\end{array}$ & $\begin{array}{r}72 \\
310\end{array}$ & $\begin{array}{l}340 \\
600\end{array}$ & $\begin{array}{r}24 \\
120\end{array}$ & $\begin{array}{r}72 \\
260\end{array}$ & $\begin{array}{l}300 \\
700\end{array}$ \\
\hline \multicolumn{11}{|c|}{ Height of fall $7 \cdot 4 \mathrm{~m}$} \\
\hline $\mathbf{3}$ & $\begin{array}{l}\text { Total } \\
+ \text { spores }\end{array}$ & $\begin{array}{l}37 \\
85\end{array}$ & $\begin{array}{r}75 \\
190\end{array}$ & $\begin{array}{l}230 \\
400\end{array}$ & $\begin{array}{l}48 \\
88\end{array}$ & $\begin{array}{r}86 \\
180\end{array}$ & $\begin{array}{l}180 \\
450\end{array}$ & $\begin{array}{r}48 \\
160\end{array}$ & $\begin{array}{l}160 \\
220\end{array}$ & $\begin{array}{l}350 \\
550\end{array}$ \\
\hline 4 & $\begin{array}{l}\text { Total } \\
+ \text { spores }\end{array}$ & $\begin{array}{r}20 \\
115\end{array}$ & $\begin{array}{r}62 \\
210\end{array}$ & $\begin{array}{l}320 \\
400\end{array}$ & $\begin{array}{l}21 \\
82\end{array}$ & $\begin{array}{r}58 \\
160\end{array}$ & $\begin{array}{l}140 \\
400\end{array}$ & $\begin{array}{r}22 \\
230\end{array}$ & $\begin{array}{r}68 \\
480\end{array}$ & $\begin{array}{l}280 \\
750\end{array}$ \\
\hline 5 & $\begin{array}{l}\text { Total } \\
\text { + spores }\end{array}$ & $\begin{array}{l}23 \\
60\end{array}$ & $\begin{array}{r}70 \\
140\end{array}$ & $\begin{array}{l}260 \\
300\end{array}$ & $\begin{array}{r}23 \\
130\end{array}$ & $\begin{array}{r}90 \\
300\end{array}$ & $\begin{array}{c}45 \\
800 ?\end{array}$ & $\begin{array}{r}21 \\
180\end{array}$ & $\begin{array}{r}60 \\
440\end{array}$ & $\begin{array}{c}330 \\
1000 ?\end{array}$ \\
\hline
\end{tabular}

Total $=$ values for total droplets. + spores $=$ values for droplets carrying spores.

is stressed here, rather than the median volume usually preferred in aerosol studies, because the number of infective units is probably more significant in plant pathology.

Droplet diameters were estimated as varying from $5 \mu$ to about $2400 \mu$. Under the conditions of the experiments few drops smaller than $30 \mu$ carried spores, the proportion decreasing with thick films. Median droplet size is slightly lower with large incident drops. The median size of droplets carrying spores appears to increase slightly with film thickness. The spore-transporting power of droplets can be expressed by extracting from the original data the mean diameters of those droplets which carry one (and only one) spore (Table 8). 
Table 8. Mean diameter $(\mu)$ of droplets carrying only one spore

Target film with 160,000 spores $/ \mathrm{cm}^{2}$

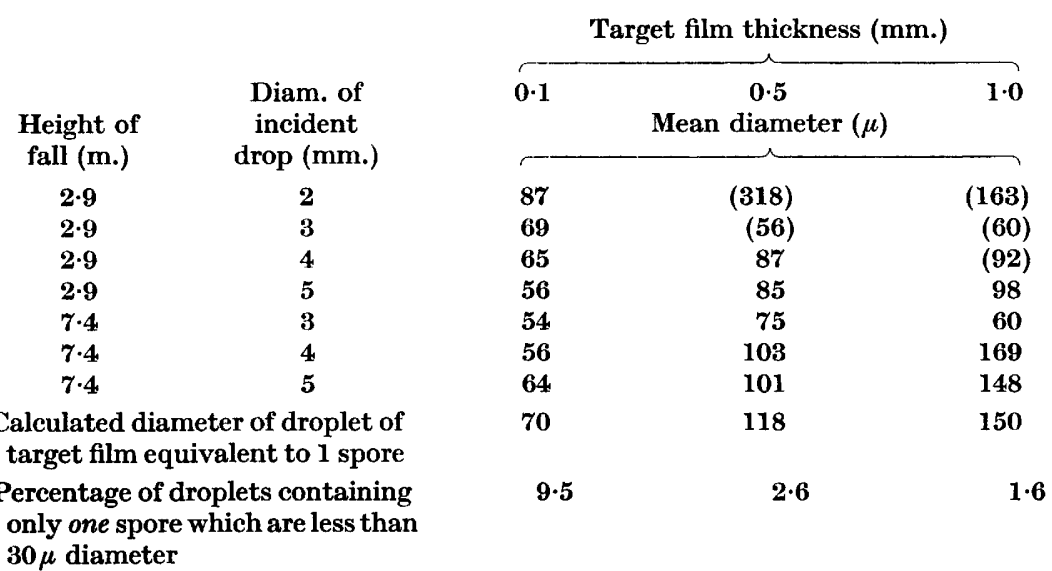

Numbers in parentheses are means based on less than five droplets.

Horizontal travel of droplets in still air. The maximum horizontal distance to which droplets are splashed on the plane of the target in still air was about $100 \mathrm{~cm}$. (Faulwetter recorded $125 \mathrm{~cm}$.). Most droplets had a shorter trajectory and few reached $100 \mathrm{~cm}$. (the limit used in the main series of experiments). The data are conveniently presented by the method used for droplet size, and the distances to which 16,50 and $84 \%$ of the droplets were thrown are entered in Table 9.

Table 9. Horizontal distance of travel of droplets (all sizes) in still air

\section{Diameter of \\ incident}

drop (mm.)

Height of fall $2.9 \mathrm{~m}$.

$\begin{array}{ll}2 & \text { Total } \\ & + \text { spores } \\ & \text { Total }\end{array}$

Total
+ spores

4 Total

5 Total

+ spores

Height of fall $7 \cdot 4 \mathrm{~m}$.

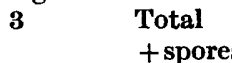

4 Total

5 Total

Target film thickness (mm.)

\begin{tabular}{|c|c|c|c|c|c|c|c|c|}
\hline \multicolumn{3}{|c|}{$0 \cdot 1$} & \multicolumn{3}{|c|}{0.5} & \multicolumn{3}{|c|}{$1 \cdot 0$} \\
\hline $16 \%$ & $50 \%$ & $84 \%$ & $\begin{array}{c}16 \% \\
\text { Distance }\end{array}$ & $\begin{array}{l}50 \% \\
\text { of tra }\end{array}$ & $\begin{array}{c}84 \% \\
\text { vel }(\mathrm{cm}\end{array}$ & $16 \%$ & $50 \%$ & $84 \%$ \\
\hline
\end{tabular}$$
4
$$$$
4
$$$$
6
$$

82

82

920

9
14

$9 \quad \mathbf{2 0}$

$13 \quad 30$

$\begin{array}{ll}13 & 30 \\ 13 & 36\end{array}$

$18 \quad 50$

3
0
50

$3 \cdot 5$
$?$
4
4
4
4
5
9

$\begin{array}{rc}8 & 20 \\ ? & ? \\ 9 & 20 \\ 14 & 30 \\ 9 & 20 \\ 11 & 30 \\ 13 & 36 \\ 28 & 50\end{array}$

20

20

30

20

20

36

30

$\begin{array}{lllllllll}6 & 13 & 33 & 5 & 10 & 31 & 8 & 21 & 32\end{array}$

$\begin{array}{lllllllll}7 & 14 & 30 & 5 & 14 & 23 & 7 & 21 & 34\end{array}$

$\begin{array}{lllllllll}5 & 12 & 36 & 5 & 11 & 27 & 6 & 18 & 32\end{array}$

$\begin{array}{lllllllll}9 & 30 & 48 & 7 & 20 & 35 & 6 & 18 & 39\end{array}$

$\begin{array}{lllllllll}5 & 10 & 35 & 5 & 10 & 23 & 5 & 9 & 93\end{array}$

+ spores

5

35

55

14

28

23 
The median horizontal distance travelled by droplets of all size categories varied from 8 to $18 \mathrm{~cm}$. in the different experiments, increasing very little with the diameter of the incident drop, its height of fall, and the film thickness. Probably air resistance limits the flight of the small droplets.

Spore-carrying droplets were also insensitive to varying conditions. Their mean distance of travel tended to be greater than the mean for all droplets because very small drops tend to be spore-free and to travel only short distances. The greatest distances were travelled by medium size droplets (most of which carried spores under the conditions tested) especially in drops with the highest kinetic energy falling on to thin films.

Deposition/unit area on plane of target. The foregoing analysis of splash is relevant to the activity of raindrops in spore dispersal. Table 4 can be recalculated to give the average numbers of droplets deposited $/ \mathrm{cm} .{ }^{2}$ in the horizontal plane of the target, giving information relevant to the possibility of a healthy plant becoming contaminated from a nearby source in still air. Data for the $\mathbf{0 . 1} \mathbf{~ m m}$. films hit by various drops are given in Table 10. In still air the probability of contamination from a single splash decreases to a low value at the distance of $1 \mathrm{~m}$.

Interaction of droplet size and horizontal travel. Droplets of different sizes had different maximum limits of horizontal travel, but apparently no minimum. The full data obtained on the relations between droplet size and distance of travel are illustrated in Fig. 7 by results of a typical experiment (drops $4 \mathrm{~mm}$. diam. falling $7 \cdot 4 \mathrm{~m}$. on to a film $0 \cdot 1 \mathrm{~mm}$. thick.) Separate curves for five or six distances are plotted showing cumulative percentage of total droplets against increasing diameters. In this experiment, for example, $95 \%$ of droplets falling 2-4 cm. from point of impact were less than $100 \mu$ in diameter. At greater distances larger droplets predominate and only $20 \%$ of the droplets falling beyond $17.5 \mathrm{~cm}$. were less than $100 \mu$ in diameter. Figure 7 is typical of the main series of experiments and the data reveal no clear trend with the various conditions tested. However, the absolute numbers of droplets (and of spore-carrying droplets) at each distance vary with the conditions; these data are summarized in Fig. 9.

Spore suspension in incident drop instead of in target film. Because of its bearing on the dispersal of spores in water dripping off foliage and splashing, the standard arrangement was reversed, using $5 \mathrm{~mm}$. diam. drops of a suspension of $16 \times 10^{6}$ macroconidia of Fusarium solani $/ \mathrm{ml}$. falling $2.9 \mathrm{~m}$. on to a target film of pure water. The droplets were caught over a representative range of 5-10 cm. from the target. In Table 11 their numbers are compared with those from the standard arrangement of water splashing on to a spore suspension in the film and show that splash droplets are composed of liquid from the incident drop and from the surface film.

\section{Vertical travel}

The vertical range of splash droplets was studied under one set of conditions only, using an incident drop $5 \mathrm{~mm}$. diam. falling from $7.4 \mathrm{~m}$. on to a film $0 \cdot 1 \mathrm{~mm}$. thick. Naphthol green slides were arranged vertically one above the 
344

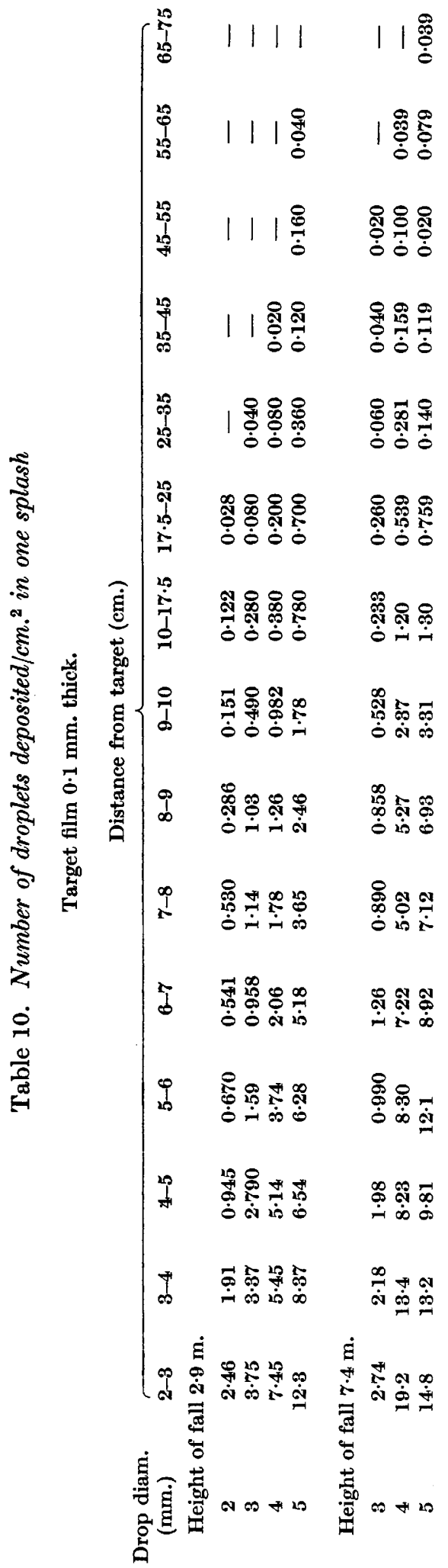


Table 11. Numbers and diameters of droplets when spore suspension is in incident drop compared with normal arrangement (suspension in target film)

Incident drop $5 \mathrm{~mm}$. diam. falling $2.9 \mathrm{~m}$.

Target film thickness (mm.)

\begin{tabular}{|c|c|c|}
\hline \multicolumn{3}{|c|}{ Conditions } \\
\hline $\begin{array}{l}\text { Incident } \\
\text { drop }\end{array}$ & $\begin{array}{c}\text { Target } \\
\text { film }\end{array}$ & Droplets \\
\hline Tap water & $\begin{array}{l}\text { Spores } \\
16 \times 10^{6} / \mathrm{ml} \text {. }\end{array}$ & $\begin{array}{l}\text { Total } \\
\text { + spores }\end{array}$ \\
\hline $\begin{array}{l}\text { Spores } \\
16 \times 10^{6} / \mathrm{ml} \text {. }\end{array}$ & Tap water & $\begin{array}{l}\text { Total } \\
\text { + spores }\end{array}$ \\
\hline
\end{tabular}

\begin{tabular}{|c|c|c|c|c|c|c|c|}
\hline \multicolumn{4}{|c|}{$0 \cdot 1$} & \multicolumn{4}{|c|}{$1 \cdot 0$} \\
\hline No. & $\begin{array}{r}16 \% \\
I\end{array}$ & $\begin{array}{l}50 \% \\
\text { m. ( }\end{array}$ & $84 \%$ & No. & $16 \%$ & $\begin{array}{l}50 \% \\
\text { iam. }\end{array}$ & ${ }^{84 \%}$ \\
\hline 876 & 20 & 31 & 80 & 462 & 23 & 34 & 300 \\
\hline 200 & 57 & 96 & 350 & 118 & 140 & 400 & 1000 \\
\hline 886 & 19 & 28 & 60 & 520 & 22 & $\mathbf{3 3}$ & 70 \\
\hline 261 & 26 & 52 & 200 & 192 & 28 & 48 & 400 \\
\hline
\end{tabular}

Table 12. Numbers of droplets travelling further than selected distances as determined by vertical and horizontal slides

Incident drop $5 \mathrm{~mm}$. diam. falling $7 \cdot 4 \mathrm{~m}$. on to film $0.1 \mathrm{~mm}$. thick.

\begin{tabular}{|c|c|c|c|c|}
\hline \multirow[b]{2}{*}{$\begin{array}{l}\text { Distance from } \\
\text { source }(\mathrm{cm} .)\end{array}$} & \multicolumn{2}{|c|}{$\begin{array}{l}\text { Vertical slides } 0-40 \mathrm{~cm} . \\
\text { above target }\end{array}$} & \multicolumn{2}{|c|}{$\begin{array}{l}\text { Horizontal slides } 2-100 \mathrm{~cm} \text {. } \\
\text { on plane from target }\end{array}$} \\
\hline & $\begin{array}{l}\text { Total no. } \\
\text { of droplets }\end{array}$ & $\begin{array}{c}\text { Droplets } \\
\text { carrying } \\
\text { spores } \\
\text { (\% total) }\end{array}$ & $\begin{array}{l}\text { Total no. } \\
\text { of droplets }\end{array}$ & $\begin{array}{c}\text { Droplets } \\
\text { carrying } \\
\text { spores } \\
\text { (\% total) }\end{array}$ \\
\hline $\mathbf{2 . 5}$ & 6340 & 24 & $\mathbf{5 2 6 0}$ & 42 \\
\hline $5 \cdot 5$ & 3580 & 24 & 4480 & 44 \\
\hline $9 \cdot 5$ & 2920 & 53 & 2940 & 57 \\
\hline 15 & 2200 & 51 & 2710 & 59 \\
\hline 20 & 1360 & 69 & 1860 & 67 \\
\hline 30 & 1880 & 82 & 1100 & 78 \\
\hline 40 & 646 & 100 & 839 & 88 \\
\hline 50 & 960 & 72 & 539 & 100 \\
\hline 60 & 453 & 70 & 476 & 100 \\
\hline
\end{tabular}

other on a frame to form a continuous test surface $40 \mathrm{~cm}$. high with its base crossing the radius at right angles at a different distance in each of nine experiments. The total number of droplets/splash intercepted at the various distances was estimated by multiplying the number of stains observed by $360^{\circ} / \theta^{\circ}$ where $\theta^{\circ}$ is the angle subtended by the sampling slide. In Table 12 these estimates of numbers of droplets intercepted are compared with the estimated numbers of droplets deposited beyond this distance in the appropriate experiment on horizontal travel. Median droplet height is shown in Table 13. The total numbers of droplets intercepted varied with height and distance as shown in Fig. 10.

Droplet diameters. Both the height and distance reached by droplets increased directly with increase in their diameter up to about 164 $\mu$. Maximum height, as well as horizontal range, appeared to be attained by droplets of intermediate size ranging from 164 to $328 \mu$ diam. (or even to $655 \mu$ ). The few large droplets of approximately 1000-2000 $\mu$ diam., which were observed when large incident drops fell at about $50 \%$ of their terminal velocity into thick films, were mostly deposited within 3 or $4 \mathrm{~cm}$. (Table 14). 


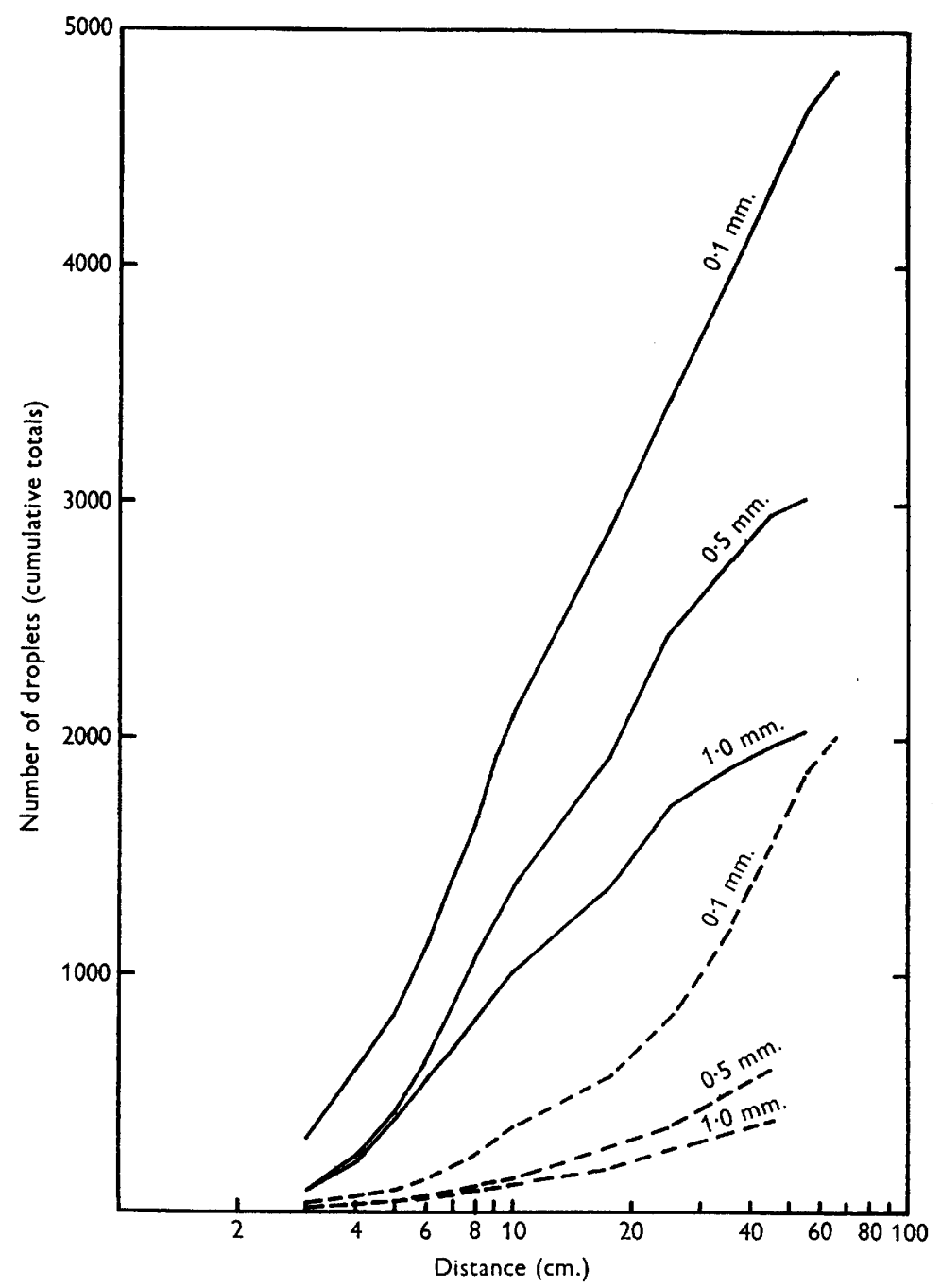

Fig. 8. Cumulative totals of all droplets (continuous lines) and droplets with spores (broken lines) from single splashes of drops $4 \mathrm{~mm}$. in diameter falling $7.4 \mathrm{~m}$. into target films of different thicknesses.

\section{Splash on fungus fructification}

The model studied in the main series of experiments is a relatively simple one and in the field pathogenic micro-organisms are exposed to rain splash at a complex variety of angles, roughnesses, sizes, etc. To test the relevance of our model to field conditions drops were allowed to splash on a twig of sycamore (Acer pseudoplatanus) bearing the pink cushion-like conidial fructifications of Nectria cinnabarina. The twig was supported at an angle of $45^{\circ}$ at a height of $10 \mathrm{~cm}$. above the sampling table. After wetting the twig in water, 5 drops, each $5 \mathrm{~mm}$. in diam., were allowed to fall on the target from a height of $7 \cdot 4 \mathrm{~m}$. 


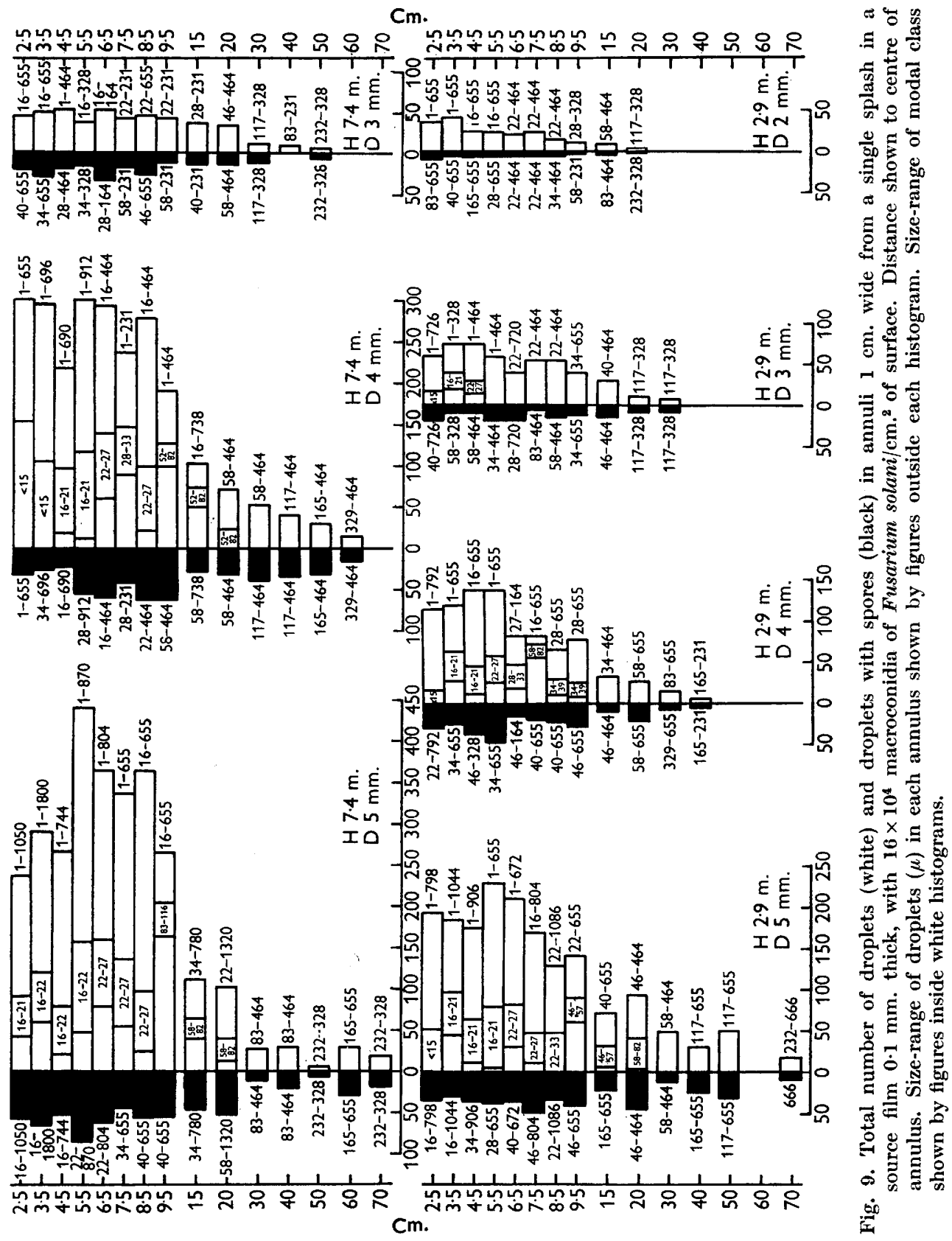


Naphthol green slides were spaced in a rectangular pattern of rows and columns to sample splash in all directions up to a maximum distance of $50 \mathrm{~cm}$. (Fig. 11). An estimated total of 2600 droplets was produced/incident drop. The size

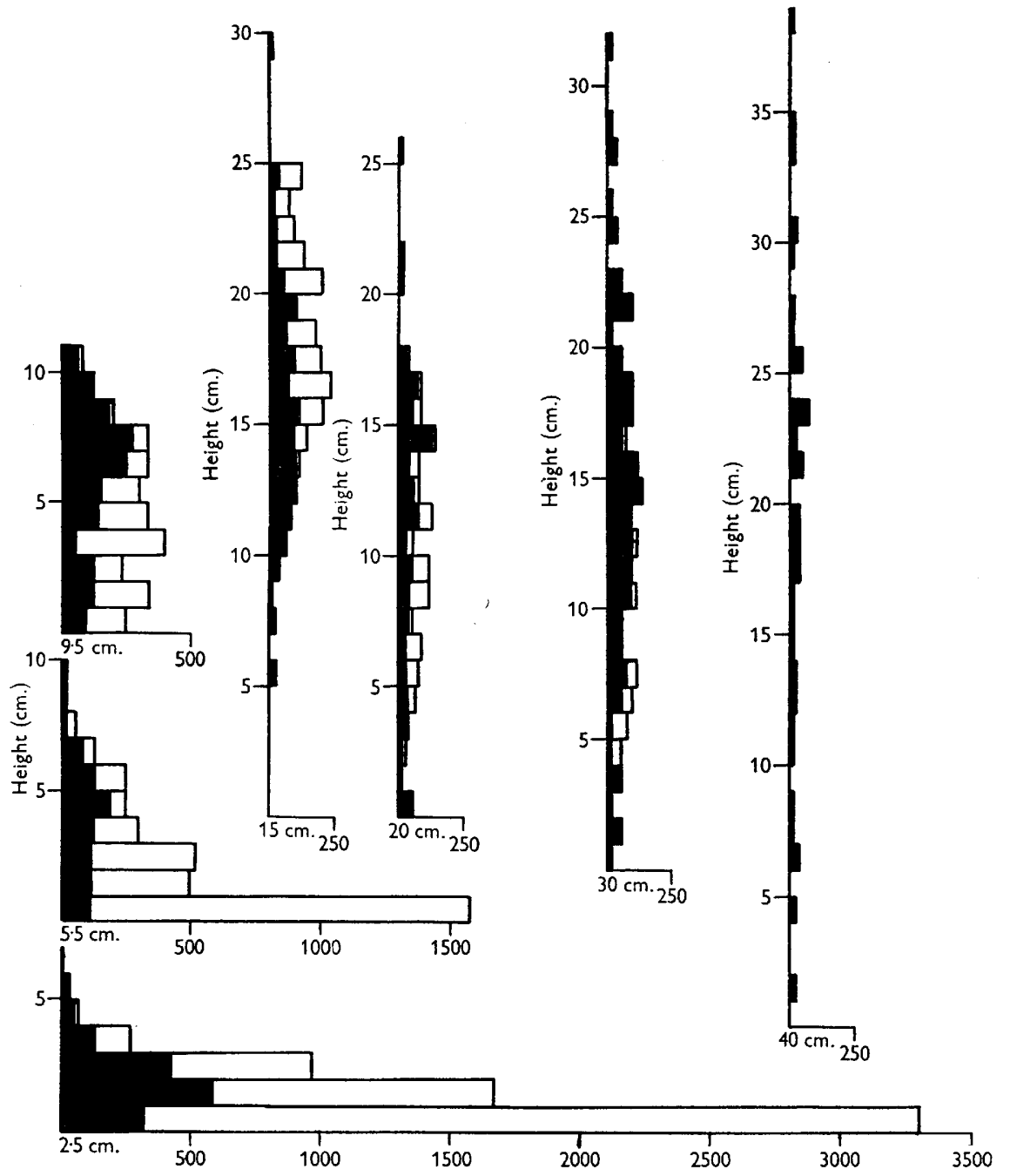

Fig. 10. Total number of droplets (black and white) and droplets with spores (black only) classified in heights at different distances from a single splash by a drop $5 \mathrm{~mm}$. in diameter falling $7 \cdot 4 \mathrm{~m}$. into a source film $0 \cdot 1 \mathrm{~mm}$. thick with 160,000 macroconidia of Fusarium solani/cm. ${ }^{2}$ of surface.

spectrum is compared with that from a thin film on a horizontal glass surface under similar conditions in Table 15 . Splash from a wet twig at $45^{\circ}$ produced both smaller and fewer droplets than splash from a horizontal slide (Fig. 12). However, all the droplets from the Nectria splash carried spores, mostly 10 or more. Figure 11 shows the numbers of droplets deposited/cm. ${ }^{2}$ in different positions for a single splash. 
Table 13. Heights reached by droplets at selected distance from target

(based on cumulative percentage)

\begin{tabular}{|c|c|c|c|c|}
\hline $\begin{array}{c}\text { Distance } \\
\text { (cm.) }\end{array}$ & & $\begin{array}{l}16 \% \\
\text { (cm.) }\end{array}$ & $\begin{array}{l}\mathbf{5 0} \% \\
\text { (cm.) }\end{array}$ & $\begin{array}{l}84 \% \\
(\mathrm{~cm} .)\end{array}$ \\
\hline $2 \cdot 5$ & $\begin{array}{c}\text { Total } \\
+ \text { spores }\end{array}$ & $\begin{array}{l}<1 \\
<1\end{array}$ & $\begin{array}{r}<1 \cdot 0 \\
1.6\end{array}$ & $\begin{array}{l}2 \cdot 3 \\
3 \cdot 0\end{array}$ \\
\hline $\mathbf{5 \cdot 5}$ & ," & $\begin{array}{l}1 \cdot 0 \\
1 \cdot 4\end{array}$ & $\begin{array}{l}1 \cdot 5 \\
4 \cdot 0\end{array}$ & $\begin{array}{l}4 \cdot 4 \\
6 \cdot 2\end{array}$ \\
\hline $9 \cdot 5$ & ", & $\begin{array}{l}1 \cdot 7 \\
2 \cdot 3\end{array}$ & $\begin{array}{l}4 \cdot 8 \\
6 \cdot 4\end{array}$ & $\begin{array}{l}7 \cdot 8 \\
9 \cdot 0\end{array}$ \\
\hline 15 & ", & $\begin{array}{l}13 \cdot 0 \\
11 \cdot 0\end{array}$ & $\begin{array}{l}17 \cdot 5 \\
15 \cdot 0\end{array}$ & $\begin{array}{l}21 \cdot 0 \\
20 \cdot 5\end{array}$ \\
\hline 20 & ,", & $\begin{array}{l}5 \cdot 0 \\
5 \cdot 0\end{array}$ & $\begin{array}{l}11 \cdot 0 \\
12 \cdot 0\end{array}$ & $\begin{array}{l}15 \cdot 5 \\
16 \cdot 5\end{array}$ \\
\hline 30 & ," & $\begin{array}{l}6 \cdot 5 \\
7 \cdot 0\end{array}$ & $\begin{array}{l}13 \cdot 5 \\
14 \cdot 5\end{array}$ & $\begin{array}{l}20 \cdot 0 \\
21 \cdot 5\end{array}$ \\
\hline 40 & ", & $\begin{array}{l}8.5 \\
8.5\end{array}$ & $\begin{array}{l}19 \cdot 5 \\
19 \cdot 5\end{array}$ & $\begin{array}{l}26 \cdot 0 \\
26 \cdot 0\end{array}$ \\
\hline
\end{tabular}

Table 14. Vertical and horizontal travel of droplets according to size

\begin{tabular}{|c|c|c|c|c|}
\hline \multirow{2}{*}{$\begin{array}{c}\text { Droplet } \\
\text { diameters } \\
(\mu)\end{array}$} & \multicolumn{2}{|c|}{ Vertical height (cm.) } & \multicolumn{2}{|c|}{ Horizontal range (cm.) } \\
\hline & Mode & Maximum & Mode & Maximum \\
\hline \multicolumn{5}{|c|}{ Values increasing with droplet diameter: } \\
\hline $10-40$ & $\ngtr 2 \cdot 5$ & $2-17$ & $2-8$ & 0-30 \\
\hline $40-164$ & $5-7 \cdot 5$ & 17-25 & 10-25 & $0-45$ \\
\hline $164-655$ & 25-35 & $30-40$ & $55-75$ & $0-75+$ \\
\hline \multicolumn{5}{|c|}{ Values decreasing with droplet diameter: } \\
\hline$>655$ & 10 & 25 & $17-25$ & $0-75$ \\
\hline \pm 1000 & - & - & $2-3$ & $0-17$ \\
\hline \pm 2000 & - & - & $2-3$ & $0-7$ \\
\hline
\end{tabular}

Table 15. Size spectrum of droplets produced by splash on twig (inclined at $45^{\circ}$ ) with conidial Nectria cinnabarina compared with splash on horizontal glass slide Incident drop $5 \mathrm{~mm}$. diam., falling $7 \cdot 4 \mathrm{~m}$.

$\begin{array}{lccc} & 16 \% & 50 \% & 84 \% \\ \text { Nectria twig } & 28 \mu & 52 \mu & 150 \mu \\ \text { Glass slide } & 23 \mu & 70 \mu & 260 \mu\end{array}$

The course of splashes on another twig bearing conidial fructifications of Nectria cinnabarina, horizontally and at $45^{\circ}$, is shown by photographs (Pls. 1, 2, figs. 1-10) from a film made with the Kodak ultra high-speed camera by Mr E. D. Eyles of Kodak Limited for one of the authors (P.H.G.) in 1945.

\section{DISCUSSION}

The impact of a raindrop falling on a thin film results in many splash droplets being thrown into the air; the larger the incident drop the greater the number of droplets. The highest value observed, 5260 droplets/incident drop, is larger 


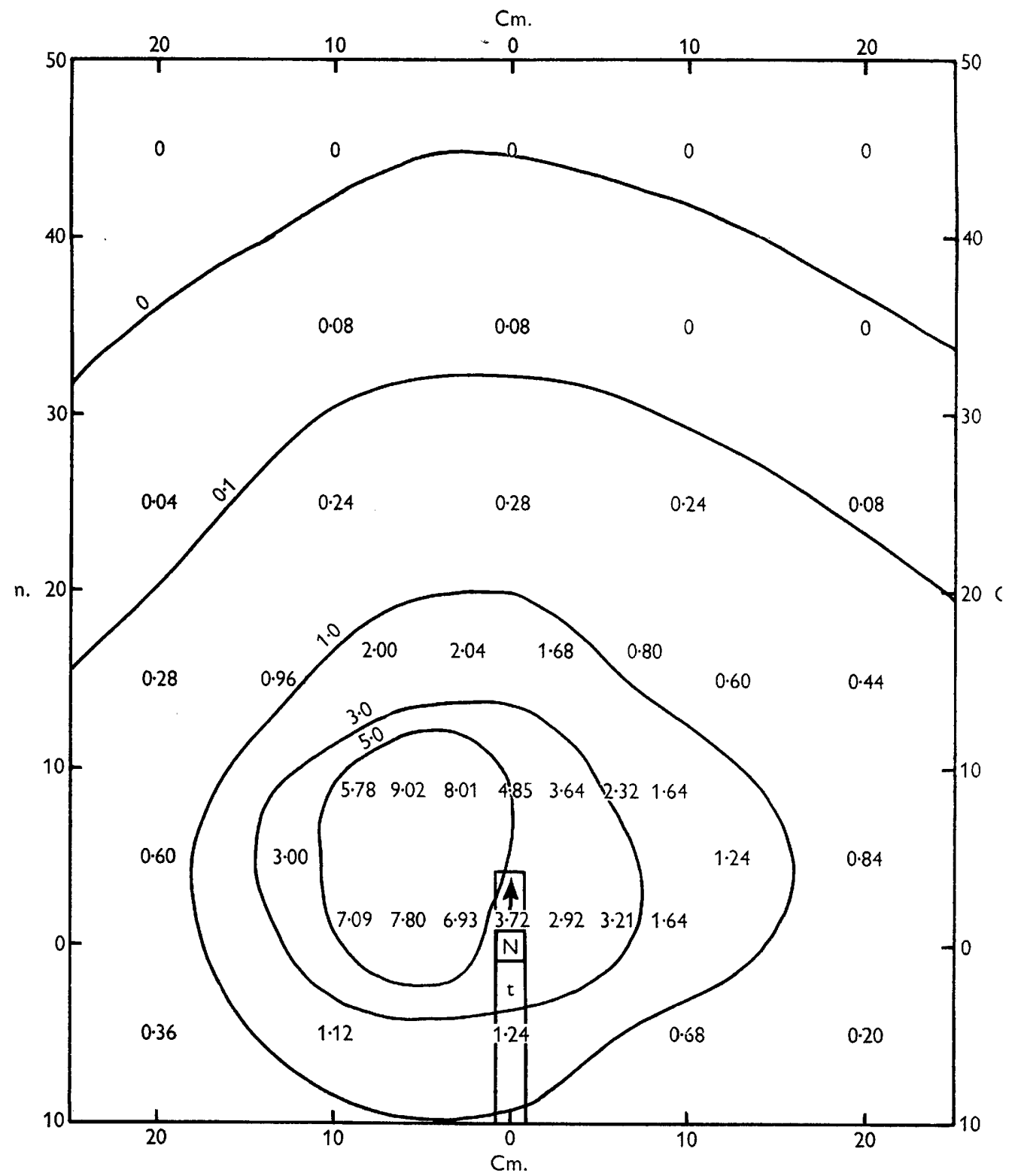

Fig. 11. Numbers of droplets/cm. ${ }^{2}$ shown for one splash from a drop $5 \mathrm{~mm}$. in diameter falling $7 \cdot 4 \mathrm{~m}$. on to a wetted twig of Acer pseudoplatanus bearing conidial fructifications of Nectria cinnabarina. $t=t w i g ; ~ \rightarrow$ shows the lower end of the twig; $N=$ position of impact of drop. 


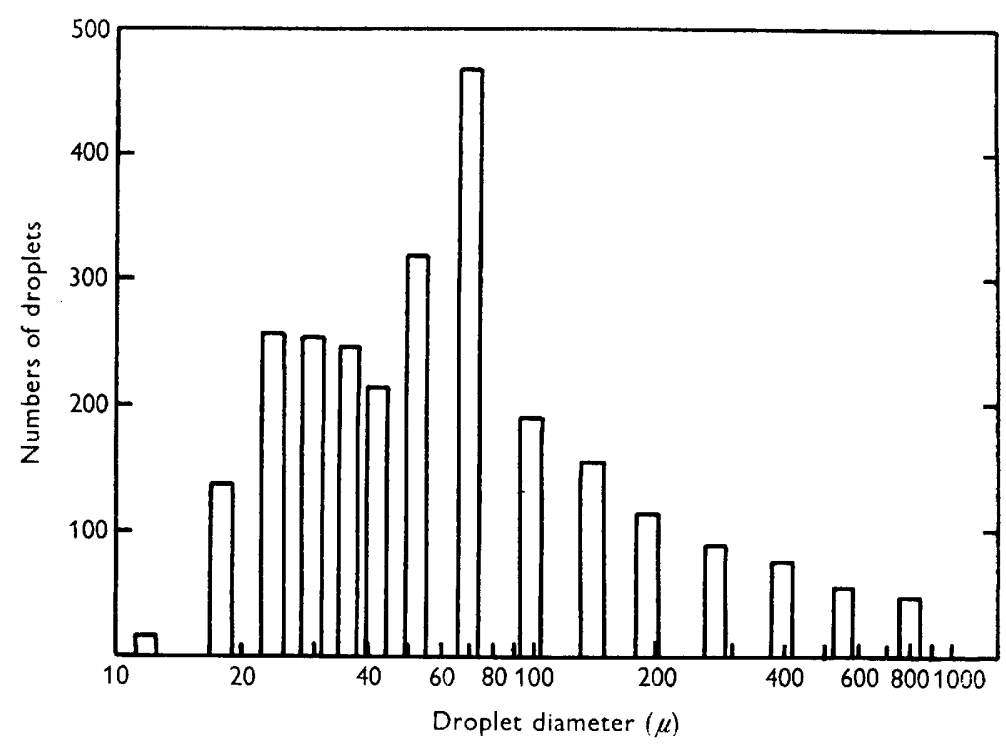

Fig. 12. Numbers of droplets classified in size-ranges from one splash from a drop $5 \mathrm{~mm}$. in diameter falling $7 \cdot 4 \mathrm{~m}$. on to a wetted twig of Acer pseudoplatanus bearing conidial fructifications of Nectria cinnabarina.

than that reported in the pioneer work of Faulwetter (1917 b), no doubt because we have used a microscope to scan very sensitive indicator slides. For the following reasons, however, even the high numbers obtained in these experiments are still probably underestimates. Any droplets smaller than those observed would probably evaporate during flight or, being too light to have a trajectory, would drift away on gentle air currents. A few droplets may have fallen beyond the 70 or $100 \mathrm{~cm}$. radius sampled. Sometimes two or more droplets overlap on the film and are counted as one, particularly when larger droplets fall near the target. In still air of the laboratory others probably fall within $2 \mathrm{~cm}$. or even on the target film although in moving air they might have functioned in spore dispersal. One factor which may have led to some over-estimation is the path taken in scanning the slides nearer the target; it might have been better, though more time-consuming, to sample random microscopic fields. Probably only the smallest drop-sizes are underestimated. The estimated numbers of larger drops carrying spores are probably unbiased but more subject to random errors when the small numbers falling at the greater distances have to be multiplied by a large factor to allow for the large area of the annulus.

Faulwetter $(1917 b)$ concluded that splash droplets consist almost solely of water from the surface film. As already reported (Gregory, 1952) it has become clear that the splash droplets are an intimate mixture of liquid from both the incident drop and the surface film. This can be demonstrated by placing a drop of green ink on a sheet of white paper and allowing a drop of red ink to fall on it from a height of 1-2 m. It is almost impossible to find a splash droplet of 
unmixed colour. Further, as Table 11 shows clearly, just as many splash droplets contain spores when the spore suspension is in the incident drop instead of in the surface film.

After a splash the target film shows a clear spore-free area several millimetres in diameter at the point of impact, sometimes surrounded by a ring of small cleared spots presumably at the base of larger rays of the splash crater. The rapid movement of liquid from the incident drop apparently sweeps the spores lying on the floor of the target film up the walls of the crater and into the droplets.

With the thinner films used in this work there is no evidence of bubble formation as described for splashes in deep layers of liquid by Worthington \& Cole (1897), Blanchard \& Woodcock (1957) and Mason (1957), but bubbles were observed in about one-third of the splashes caused by $5 \mathrm{~mm}$. drops falling $7 \cdot 4 \mathrm{~m}$. into a deep film $(1.0 \mathrm{~mm}$. thick).

Splash dispersal in still air appears more local, producing a steeper gradient, than eddy diffusion of dry air-borne spores. The interior of a herb, bush or tree is a region where spore movement readily takes place in any direction by splash. A splash is of momentary duration, and dispersal appears unlikely to be further limited during rain by pick-up of droplets by raindrops. On the contrary, whereas a dry spore when once deposited is best considered 'out of play' as a first approximation, a splash-dispersed spore deposited on a wet surface is presumably susceptible to re-splash, so that continued rain may extend rather than limit the range of dispersal.

Dispersal by rain splash differs markedly from the more familiar 'take-off' mechanisms in dry air. Slime spores are held firmly to the matrix during dry periods and only set free in the kind of weather which is suitable for spore germination. The energy of raindrops is then available for their dispersal in splash droplets. The abundant smaller raindrops carry little energy and throw up few splash droplets. The larger, faster moving raindrops on the other hand are energetic producers of droplets. Spores carried in splash droplets during continued rain may be washed out of the air at once by other raindrops, or they may be washed off a surface on which they have been deposited. When carried by large droplets they may follow a definite trajectory, or when in small droplets they may behave after take-off like dry spores. The modification of the trajectories of splash droplets by wind was examined briefly by Faulwetter $(1917 a, b)$ but has apparently not been re-investigated since. Because they reach greater heights the droplets of medium diameter appear more likely to be carried off by wind.

While the largest raindrops falling at their terminal velocity appear most active in rain splash, experiments with fall heights between 2 and $3 \mathrm{~m}$. show that much splash dispersal can also occur with large drops falling at only $50 \%$ of their terminal velocity. Such drops can occur both during overhead irrigation and under natural conditions in woodlands and within the frame of a single tree or bush. Further, leaves accumulate water and release large drops when wetted by mist, fog, and drizzle which all have drop sizes too small themselves to be significant splash producers. Drip from vegetation as well 
as impact of raindrops appears significant in spore dispersal by splash droplets (Faulwetter, 1917b; Gregory, 1952; Hirst, 1958). The mechanism is equally effective in dispersing spores either when water falls on to a film containing spores, or when a spore suspension from a leaf falls on to a spore-free surface film. Surface tension effects are likely to be significant in these circumstances.

Finally, splash dispersal can raise spores vertically. It is one of the mechanisms by which spores can be thrown into turbulent air and so remain in suspension for long periods. Alternatively, it is a method by which spores can climb upwards in a plant or a group of plants from a fructification lower down.

While macroconidia of Fusarium solani were readily removed from thin films in droplets of all diameters down to $50 \mu$, few were found in droplets smaller than $30 \mu$. It is not clear whether this lower limit is imposed by the size and shape of the spores or by the concentration of the spore suspension. The smaller spores of Colletotrichum lindemuthianum and Gloeosporium album are even more easily removed from thin films. Conidia of Nectria cinnabarina (Tubercularia state) and cells of Escherichia coli are very readily splashed. The ease with which spores of different shapes, sizes and surface are removed from various rigid and non-rigid plant surfaces requires study. So also does the splash from drops of $1 \mathrm{~mm}$. diam. and less which are abundant in rain. The dispersal of micro-organisms by splash is not only feasible but is likely to be a highly effective process.

We wish to thank the Department of Scientific and Industrial Research for financial support for one of us (E.J. G.) and to thank: Mr J. B. Byass, National Institute of Agricultural Engineering, Silsoe; Mr E. D. Eyles of Kodak Limited; the staff of the Meteorological Department of Imperial College; and Messrs R. Adams and A. Horne of this Department for technical help.

\section{REFERENCES}

Best, A. C. (1950). The size distribution of raindrops. Quart. J. R. met. Soc. 76, 16.

Blanchard, D. C. \& Woodcock, A. H. (1957). Bubble formation in the sea and its meteorological significance. Tellus, 9,145 .

Courshee, R. J. \& Byass, J. B. (1953). Preparation and calibration of glass slides for sampling sprays. Rep. Nat. Inst. agric. Engng Silsoe, no. 32.

Edgerton, H. E. \& Killian, J. R. (1939). Flash: Seeing the Unseen by Ultra HighSpeed Photography. Boston: Hale.

ENGEL, O. G. (1955). Waterdrop collisions with solid surfaces. J. Res. nat. Bur. Stand. 54, 281.

FAULwEtTER, R. C. (1917a). Dissemination of the angular leafspot of cotton. J.agric. Res. 8, 457.

Faulwetter, R. C. (1917b). Wind-blown rain, a factor in disease dissemination. J. agric. Res. 10, 639.

Green, H. L. \& Lane, W. R. (1957). Particulate Clouds: Dusts, Smokes and Mists. London: Spon.

Gregory, P. H. (1952). Fungus spores. Trans. Brit. mycol. Soc. 35, 1.

GunN, R. \& KInZEN, G. D. (1949). The terminal velocity of fall for water droplets in air. J. Met. 9, 114, 394. 
Guthrie, E. J. (1957). A Study of the Rain-Splash Dispersal of Fungi. Thesis for the Ph.D. degree of the University of London.

Hirst, J. M. (1958). Spore liberation and dispersal. (In the Press.)

LAws, J. O. (1941). Measurements of the fall-velocities of water-drops and raindrops. Trans. Amer. geophys. Un. Rept. 22nd Ann. Gen. Mtg, pp. 709-721.

Liddell, H. F. \& WootTen, N. W. (1957). The detection and measurement of water droplets. Quart. J. R. met. Soc. 83, 263.

Mason, B. J. (1957). The Physics of Clouds. Oxford University Press.

Nisikado, Y., InouYe, T. \& Oкамото, Y. (1955). Conditions of the spores of the scabbed wheat ear suspended in raindrops. Ber. Ohara Inst. 10, 125.

Stepanov, K. M. (1935). Dissemination of infective diseases of plants by air currents. Bull. Pl. Prot., Leningr. Ser. 2. Phytopathology, no. 8, pp. 1-68.

Worthington, A. M. \& Cole, R. S. (1897). Impact with liquid surface studied by the aid of instantaneous photography. Phil. Trans. A, 189, 137.

\section{EXPLANATION OF PLATES}

Photographs taken from an ultra high-speed film of a drop falling on a twig bearing conidial fructifications of Nectria cinnabarina.

\section{Prate 1}

Twig at angle of $45^{\circ}$. Fig. 1. $t=-0.006$ sec.; fig. $2, t=+0.003$ sec.; fig. $3, t=+0.012$ sec.; fig. $4, t=+0.021$ sec.; fig. $5, t=+0.033$ sec.; fig. $6, t=+0.054$ sec.

Plate 2

Horizontal twig. Fig. 7, $t=0$ sec.; fig. $8, t=0.021$ sec.; fig. 9, $t=0.045$ sec.; fig. $10, t=$ 0.075 sec. 
Journal of General Microbiology, Vol. 20, No. 2
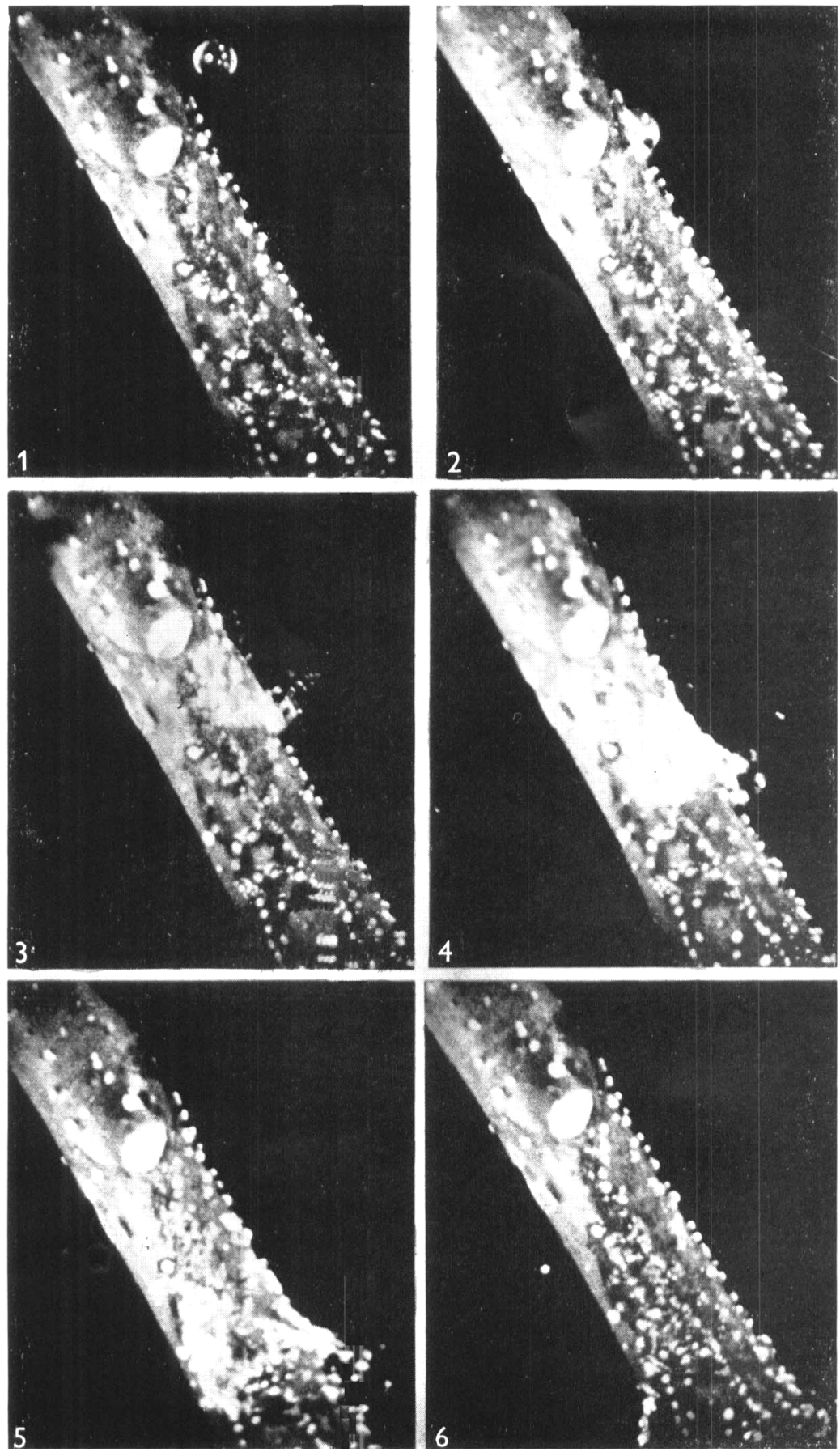

P. H. Gregory, E. J. Guthrie \& M. E. Bunce-Splash pispersal of fungus SPORES. Phate 1 
Journal of General Microbiology, Vol. 20, No. 2
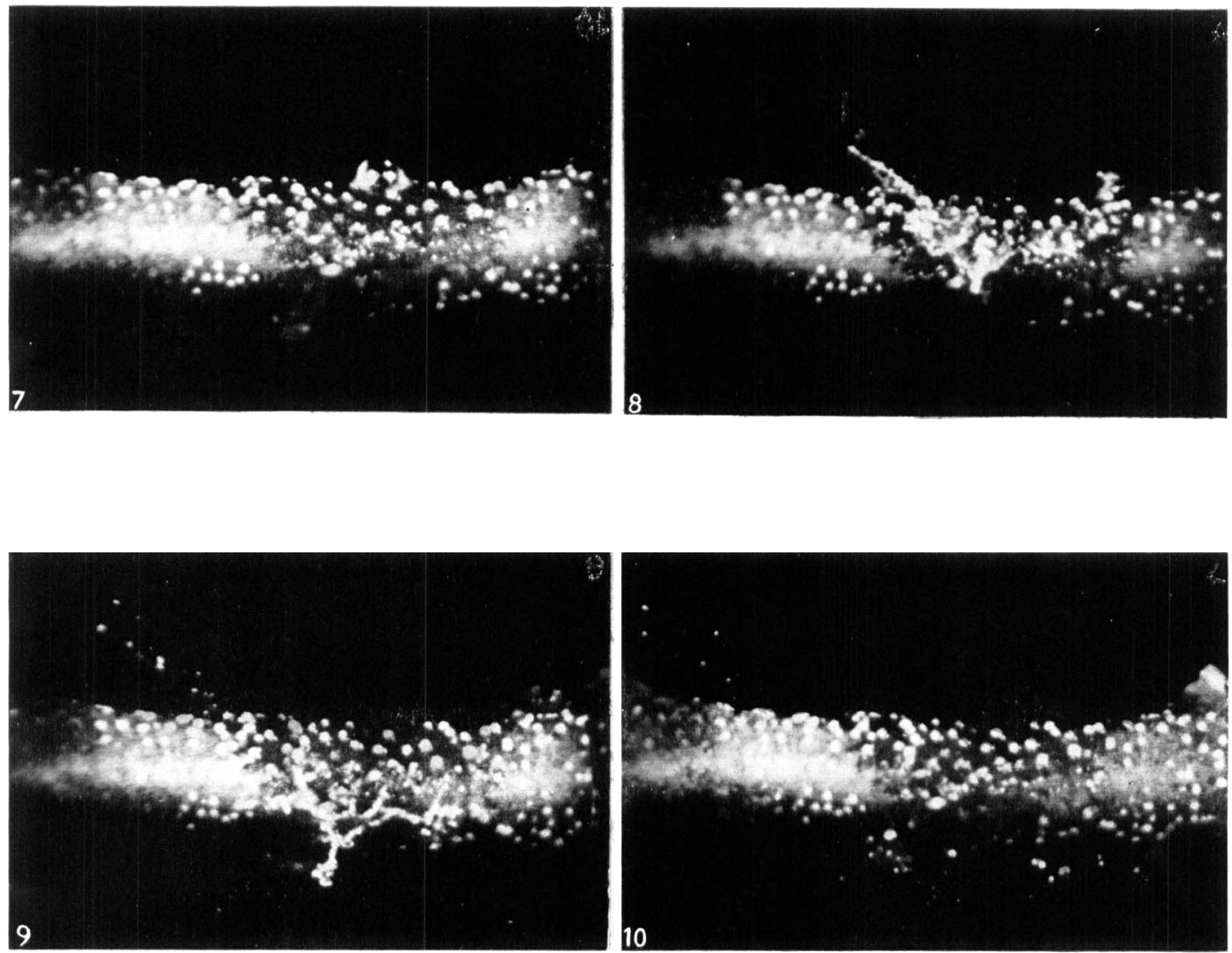

P. H. Gregory, F. J. Guthrie \& M. E. Bunce-Splasit dispersat of fungus spores. Plate 2 